\title{
Research pathways to foster transformation: linking sustainability science and social-ecological systems research
}

\author{
$\underline{\text { Andra-Ioana Horcea-Milcu }}^{1,2,3}, \underline{\text { Berta Martín-López }}^{4}, \underline{\text { David P. M. Lam }}^{4}$ and Daniel J. Lang ${ }^{4}$
}

\begin{abstract}
Although sustainability science and social-ecological systems research pursue very similar goals, i.e., generate problemand solution-oriented knowledge to foster sustainability transformation, they partly apply different research approaches and use different key concepts. Our aim is to identify archetypes of sustainability transformation research derived for sustainability science and social-ecological systems research that make knowledge from the two research pathways more accessible to each other in order to foster transformation. To reach this goal, we applied a mixed method approach toward an archetype analysis, based on semantic networks and clusters. Our findings point out that the fields of sustainability science and social-ecological systems research are rather coherent and not so distinct as may be expected, especially in terms of normative goals and addressed topics. Our analysis inductively reveals four archetypes of sustainability transformation research, with thematic structures clustered around (1) environmental change and ecosystem services; (2) resilience and vulnerability; (3) knowledge production for sustainability; and (4) governance for sustainability. We describe how these archetypes interact and facilitate dialogue between the fields. When considering the two transformation research pathways from the perspective of the research mode of transdisciplinary research, their discourses appear more disconnected. To fill this gap, we uncover key concepts that can strengthen the connection of the two fields to inform and foster sustainability transformations. These concepts involve engaging with nonacademic actors and seeking impact in policy.
\end{abstract}

Key Words: archetypes; bridging concepts; cluster; interface; knowledge; sustainability transformation research; transdisciplinary

\section{INTRODUCTION}

The need to find solution options to complex sustainability problems has advanced collaboration among scientific disciplines, as well as among science and other societal actors at the science-society or science-policy interface (e.g., Larigauderie and Mooney 2010, Cornell et al. 2013, Díaz et al. 2015, Fischer et al. 2015). Sustainability science, social-ecological systems research, resilience thinking, ecological economics, transition approaches are only a few arenas of such progress oriented toward creating societally relevant sustainability outcomes (Abson et al. 2014, Folke et al. 2016, Loorbach et al. 2017). The origins of social-ecological systems research include a strong focus on understanding complex system dynamics in situations of change and of navigating uncertainties (Gunderson and Holling 2002, Berkes et al. 2003, Folke 2006). Simultaneously, over the last decades, sustainability science evolved following a research agenda that deals with the complexity of change through the process of research itself or by advancing concepts and theories, often highlighting a tension between a rather descriptiveanalytical and a more transformative mode of sustainability science (Wiek and Lang 2016).

Sustainability science seeks to advance the understanding of social-ecological (or human-environment) dynamics to inform and facilitate the design, implementation, and testing of interventions that foster sustainability (Kates et al. 2001, Clark and Dickson 2003, Bettencourt and Kaur 2011). Similarly, socialecological systems research aims to understand humanenvironment interactions to provide the knowledge needed to support and enable sustainability transformations (Carpenter et al. 2012, Fischer et al. 2015, Leslie et al. 2015, Balvanera et al. 2017a). Although sustainability science and social-ecological systems research share the purpose of fostering sustainability transformations, they seem to partly follow different research pathways to produce, integrate, and use knowledge about and for transformation.

The way knowledge is created, shared, and used in society can crucially influence transformation processes and plays a major role in creating improved sustainability outcomes. In order to achieve its transformative goal, sustainability scientists have argued for multi-, inter-, and transdisciplinary modes of research to create more inclusive knowledge and knowledge production processes for a rather long time (Max-Neef 2005, Hadorn et al. 2008, Jahn et al. 2012, Lang et al. 2012, Scholz and Steiner 2015). More recently, social-ecological systems researchers have started adapting to less "classical" ways of knowledge production, orienting toward more transdisciplinary approaches (see Table 1; Armitage et al. 2012, Carpenter et al. 2012, Mauser et al. 2013). This is the case especially in place-based social-ecological research where the need to integrate stakeholders in the research process has led to development and adaptation of different tools and methods for more transdisciplinary endeavors (Balvanera et al. $2017 a, b$ ). In summary, sustainability science tends to focus on creating, differentiating, and integrating actionable contextualized knowledge for how to intervene in systems (Miller 2013, Wiek and Lang 2016), while social-ecological systems research tends to seek building insights relevant to address sustainability problems and find solutions (Ostrom 2009). Hence, sustainability science literature pays extensive attention to knowledge processes and practices (Spangenberg 2011, Cote and Nightingale 2012), while the inherently interdisciplinary social-ecological systems research also has a large focus on understanding and producing different types of knowledge required to transition systems toward sustainability (Jerneck et al. 2011, Partelow 2018, Colding and Barthel 2019).

\footnotetext{
${ }^{1}$ Ecosystems and Environment Research Program, Faculty of Biological and Environmental Sciences, University of Helsinki, Helsinki, Finland, ${ }^{2}$ Helsinki Institute for Sustainability Science (HELSUS), University of Helsinki, Helsinki, Finland, ${ }^{3}$ Department of Economics and Management, Faculty of Agriculture and Forestry Sciences, University of Helsinki, Helsinki, Finland, ${ }^{4}$ Faculty of Sustainability, Leuphana University of Lüneburg, Lüneburg, Germany
} 
Table 1. Glossary of terms.

\begin{tabular}{|c|c|}
\hline Archetype of research: & $\begin{array}{l}\text { Recurrent structural patterns of semantic relationships between research concepts, which encompass discursive (thematic) } \\
\text { concept clusters (authors' generated definition). }\end{array}$ \\
\hline Bridging concept: & A concept that actively links fields and stimulates dialogue (Baggio et al. 2015). \\
\hline Research pathway: & $\begin{array}{l}\text { Each of the ways to produce, integrate, and use knowledge in order to inform sustainability transformations, having } \\
\text { different points of departure and theoretical foci (authors' generated definition). }\end{array}$ \\
\hline $\begin{array}{l}\text { Research practice (e.g., } \\
\text { transdisciplinary research } \\
\text { practice): }\end{array}$ & A shared way in which science is applied and conducted (authors' generated definition). \\
\hline Semantic network: & A set of words (concepts) and the relationships among them based on word co-occurrence matrices (after Robins 2015). \\
\hline Transformation: & $\begin{array}{l}\text { Desirable, radical (as opposed to incremental), and nonlinear societal change (after (Hölscher et al. 2018). We note that for } \\
\text { the purpose of this study we employ this simplified definition recognizing it does not encompass important dimensions } \\
\text { such as power, equity, or culture. }\end{array}$ \\
\hline Transdisciplinarity: & $\begin{array}{l}\text { An integrative scientific practice whereby different academic disciplines work jointly with practitioners to solve a real- } \\
\text { world problem. We note that for the purpose of this study we employ this simplified definition recognizing it does not } \\
\text { encompass all dimensions of transdiscisplinarity. }\end{array}$ \\
\hline
\end{tabular}

Current debates on the delineations of the two research pathways argue that sustainability science and social-ecological systems research are closely related, without consistently elucidating and defining their relationship. Folke et al. (2016) plea, for instance, for a biosphere-based sustainability science, suggesting that social-ecological systems research is a subset of sustainability science (see also West 2016, Balvanera et al. 2017a) or could be considered complementary (Redman 2014). In the same vein, Brandt et al. (2013) do not consider social-ecological systems research on its own right, but rather frame it as the subject of research of sustainability science. Other authors regard them as rather divided and outline the cobenefits stemming from interlinking their insights and approaches in terms of advancing research efforts for sustainability (Kajikawa et al. 2014, Partelow and Winkler 2016, Liehr et al. 2017). For example, building academic consensus around notions such as transdisciplinarity or more strongly connecting the empirical results of the two pathways may accelerate the contribution that science can make to finding solutions toward sustainability. For the purpose of this paper, we initially treat the two research pathways as distinct.

The anticipated benefits of linking the two research pathways relate to the identification of synergies and common concepts that can contribute to informing sustainability transformations (see Table 1) and targeting different disciplinary audiences by producing rigorous knowledge. This is all the more timely especially in the context of current debates around how science could effectively contribute to facilitating transformative change, whether it should be transformative or not, and the needed clarity about its normative goals (Fazey et al. 2018, van der Hel 2018). Up to now synergies between the two pathways have been mainly indicated at a conceptual level (e.g., Partelow 2016), but not yet thoroughly analyzed. Thus, in this paper we applied a type of archetype analysis of the most relevant published literature on sustainability science and social-ecological systems research. By conducting semantic networks and cluster analysis, we aim at identifying common concepts of both research pathways and to explore the role of transdisciplinarity as part of these synergies. Archetype analysis was already applied in sustainability research to understand social-ecological dynamics (Eisenack et al. 2006) such as adaptation to climate change (Eisenack 2012), or archetypal trajectories of ecosystem services related to land-use changes (Locatelli et al. 2017). Similarly, the notion of archetypes has been used in sustainability related research to advance, for example, the understanding of pathways that link aspects of failure to sustainable productivity (Newig et al. 2019) or of socialecological rangelands systems (Hartel et al. 2018). However, the potential of this analysis still remains unexplored with regard to identifying research archetypes within sustainability transformation research.

To fill this gap, we aim to identify and characterize archetypes of sustainability transformation research found in sustainability science and social-ecological systems literature. To this end, we define archetypes of sustainability transformation research as those recurrent structural patterns of semantic relationships between research concepts, which encompass discursive (thematic) concept clusters (see Table 1). We specifically aim to (i) identify existing synergies of both research pathways; (ii) test whether transdisciplinarity acts as a bridging research mode for both research pathways; (iii) identify other potential bridging concepts that may connect the two research pathways of sustainability transformation to improve their contributions to sustainability transformations in the future.

\section{METHODS}

To identify the relevant papers on sustainability science and social-ecological systems research, we first conducted a systematic search in the Web of Science using the search strings presented in Table 2. The search was applied to title, key words, and abstract on 20 June 2016 and considered only papers published until June 2016. In an initial step, we only searched for sustainability science (586 publications) and social-ecological systems research (2532 publications; Table 3). In a subsequent step, we searched for publications that relate to transdisciplinarity and sustainability science (105 publications), and transdisciplinarity and socialecological systems research respectively (117 publications; Table $3)$.

Second, we selected those 15 publications with the highest number of citations per year, i.e., the total number of citations divided by the number of years since publication, in each of the four aforementioned combinations of search strings (Table 2). We made the assumption that these publications were representative of the dominant discourses in the existing literature. There was 
Table 2. Search terms used to identify relevant published literature on sustainability science, social-ecological systems research, and their combination with transdisciplinary mode.

\begin{tabular}{ll}
\hline \hline Sustainability transformation research & Search string \\
\hline Sustainability science & "sustainability science" \\
Social-ecological systems research & $\begin{array}{l}\text { "social-ecological system*" or "human-environment* system*" or "human-nature system*" or "human } \\
\text { and natural system*" or "human-natural system*" } \\
\text { (transdisciplinar* or co-design* or codesign* or co-produc* or coproduc*) }\end{array}$ \\
Transdisciplinary &
\end{tabular}

an overlap of nine articles among the selected total of 60 (Table A1.1). We analyzed the core 51 selected publications using VOSviewer (van Eck and Waltman 2010), a software that enables visualizing knowledge landscapes by creating a semantic network with the terms used in title, key words, and abstract of the selected publications. Semantic network analysis or relational content analysis appeared as an alternative to the content analysis method in order to overcome its drawbacks related to coder interpretation and the reduction of data complexity to nonstructured categories (van Atteveldt 2008). In the semantic network, nodes represent words (Fig. 1). The relative size of nodes represents the frequency of each word in publications (Sedighi 2016). The interlinkages (edges) between the different words represent the number of cooccurrence of pairs of words, which results in different distances between two nodes. The smaller the distance between a pair of words, the higher the co-occurrence in the analyzed publications (Certomà et al. 2015). The selection of words for depicting the networks was based on two main criteria. First, we set a threshold of words occurrence whereby words should appear at least in the abstract of five publications (Table 3). Second, words should have a clear meaning in the context of sustainability transformation research and therefore we deleted those words representing prepositions or articles. We used our expert knowledge to delineate the fine threshold between terms that represent a research pathway and general terms irrelevant to the analysis such as, e.g., study, aim, face, addition, or term, among others. We removed the general terms for further analysis (see Table A2.1 for the full set of excluded words). Words were not lemmatized (see, e.g., Table A3.1, A4.1).

Fig. 1. Graphical example illustrating nodes, edges, and the network metrics (after van Atteveldt 2008). In the network representation, the circles represent the nodes and the arrows represent the edges. The network representation is a visual illustration of network metrics.

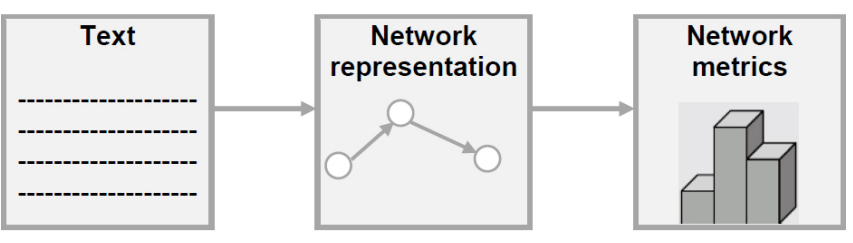

Using modularity-based clustering and the frequency of word cooccurrence we also inductively identified clusters for each semantic network. The VOSViewer cluster technique is a novel technique for modularity-based clustering, which employs clustering algorithms that use modules to measure the strength of communities (Newman and Girvan 2004, Newman 2006). The modularity-based clustering of VOSViewer is a variant of the cluster algorithm developed by Clauset et al. (2004) to detect communities (clusters) in a network that also considers modularity, a measure that evaluates the quality of the community (cluster) structures (Newman and Girvan 2004). In this way, the modularity-based clustering of VOSViewer, which was developed by Waltman et al. (2010), provides networks in which nodes are densely connected internally within clusters, but loosely connected externally between different clusters (Yan et al. 2012). This clustering technique has two main advantages: first, it unifies mapping and clustering approaches, and second, it partitions the research conducted in papers more effectively than traditional cluster methods such as k-means (Yan et al. 2012). We ran the modularity-based clustering separately for each semantic network.

By combining semantic networks with cluster analysis in VOSViewer, we sought to extract and cluster concepts of sustainability science and social-ecological systems research as such, as well as in relation to transdisciplinarity. We interpret the resulting clusters as archetypes of sustainability transformation research because they tend to be repetitive across all analyzed networks, with no new clusters emerging.

We created eight semantic networks from the following sources (Fig. 2, Table 3): (1) sustainability science (SS), (2) socialecological systems research (SES), (3) sustainability transformation research (SS AND SES, joint network from sustainability science and social-ecological systems research), (4) sustainability science with transdisciplinary (SS AND TD), (5) social-ecological systems research with transdisciplinary (SES AND TD), (6) sustainability transformation research with transdisciplinary ([SS AND SES] AND TD, joint network from sustainability science, social-ecological systems research, and transdisciplinary), (7) a network from all 51 selected articles, and (8) a network from all the papers citing the 51 selected articles. Table 3 synthesizes the number of papers and words used to create each of the eight semantic networks. The networks of SS, SES, SS AND TD, SES AND TD were based on the three modular search string categories (Table 2). SS AND SES and (SS AND SES) AND TD were created to obtain a comprehensive perspective of the overall literature set (Fig. 2, Table 3). To check whether the archetypes of sustainability transformation research identified through the first six semantic networks were consistent, we created the network from the 51 articles selected in this research (Table A1.1, Fig. A5.1), and a last network with all the papers citing these 51 articles (Fig. A5.2). For each of the eight networks, we considered a different threshold of co-occurrence of words in order to level the number of words per network, ranging from 88 to 148 words 
Table 3. Summary of the semantic networks created to identify the archetypes of sustainability transformation research ontologies: number of papers found with the different search strings (Table 2), number of papers included in the analysis, number of terms extracted from titles, key words, and abstracts, threshold of occurrence of these terms, and final number of terms selected for the semantic network. Initial networks are based on search strings from Table 2.

\begin{tabular}{|c|c|c|c|c|c|c|}
\hline Semantic network & $\mathrm{N}$ papers & $\begin{array}{c}\mathrm{N} \text { papers } \\
\text { included in the } \\
\text { analysis }\end{array}$ & $\mathrm{N}$ terms & $\begin{array}{l}\text { Occurrence } \\
\text { threshold }\end{array}$ & $\begin{array}{c}\mathrm{N} \text { terms } \\
\text { included in the } \\
\text { analysis }\end{array}$ & Purpose \\
\hline Sustainability science (SS) & 586 & 15 & 12648 & 15 & 124 & Initial network \\
\hline Social-ecological systems research (SES) & 2532 & 15 & 47507 & 60 & 144 & Initial network \\
\hline $\begin{array}{l}\text { Sustainability science and transdisciplinary } \\
\text { (SS AND TD) }\end{array}$ & 105 & 15 & 2831 & 5 & 88 & Initial network \\
\hline $\begin{array}{l}\text { Social-ecological systems research and } \\
\text { transdisciplinary (SES AND TD) }\end{array}$ & 117 & 15 & 3509 & 5 & 119 & Initial network \\
\hline SS and SES (SS AND SES) & 3118 & 30 & 54056 & 70 & 148 & $\begin{array}{l}\text { Acquire a } \\
\text { comprehensive } \\
\text { perspective on the } \\
\text { archetypes }\end{array}$ \\
\hline $\begin{array}{l}\text { SS AND TD and SES AND TD } \\
\text { ([SS AND SES] AND TD) }\end{array}$ & 222 & 30 & 5130 & 10 & 94 & $\begin{array}{l}\text { Acquire a } \\
\text { comprehensive } \\
\text { perspective on the } \\
\text { archetypes }\end{array}$ \\
\hline $\begin{array}{l}\text { SS and SES and SS AND TD and SES } \\
\text { AND TD }\end{array}$ & 3340 & 51 & 54056 & 100 & 116 & $\begin{array}{l}\text { Check consistency of } \\
\text { the archetypes }\end{array}$ \\
\hline $\begin{array}{l}\text { All citing articles of SS and SES and SS } \\
\text { AND TD and SES AND TD }\end{array}$ & 13755 & 13755 & 163365 & 500 & 103 & $\begin{array}{l}\text { Check consistency of } \\
\text { the archetypes }\end{array}$ \\
\hline
\end{tabular}

(Table 3). To explore the coherence of the semantic networks we estimated their graph density. A complete graph has a maximum density of 1 , indicating that all words in the network would be tied to one another.

Fig. 2. Origins of the eight semantic networks summarized in Table 3. Each shape represents the origins of a semantic network. The rectangular borders signal the initial four semantic networks based on the search strings in Table 2. Round borders signal semantic networks resulting from joint search results from two out of the four initial semantic networks. Bold borders signal semantic networks resulting from combining search results of all four initial semantic networks. Dashed borders group networks that are represented in Figs. 3 8 and in Appendix 5 (Figs. A5.1, A5.2). Acronyms are defined as follows: SS: sustainability science, SES: social-ecological systems research, TD: transdisciplinarity.

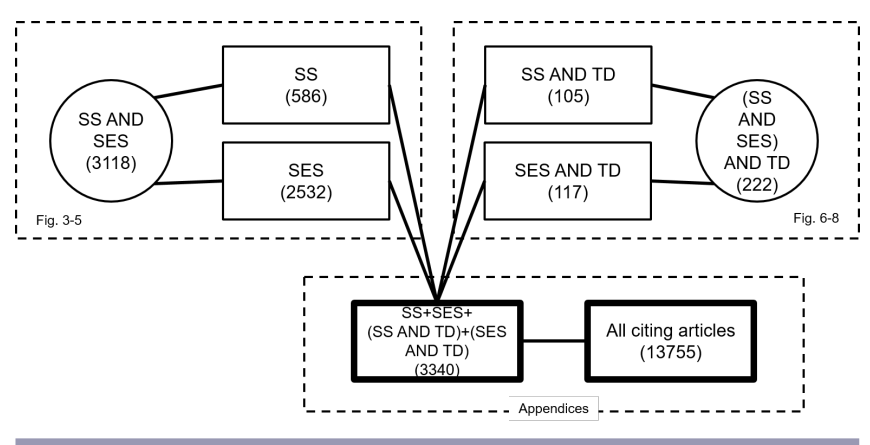

Third, we identified potential bridging concepts defined by Baggio et al. (2015) as "a concept that actively links fields and stimulates dialogue." The identification of bridging concepts relied on calculating three metrics of nodes. In line with available literature on networks (Wasserman and Faust 1994, Lü et al. 2016), the following node metrics were considered the most relevant for the aims of the study.

1. The weighted degree measures the number of edges from or to another node, i.e., word, in the network (Freeman 1978-1979), pondered by the weight of each edge (Borgatti and Everett 1997). It thus provides information of the individual contribution of each node to the interconnectedness of the network.

2. Betweenness refers to how many times a node, i.e., word, links to others that would be otherwise disconnected (Freeman 1978-1979, Wasserman and Faust 1994). Nodes with a higher betweenness exert more control over the network, hence betweenness is considered a general measure of centrality of the network (Freeman 1978-1979).

3. Eigenvector centrality refers to the influence of a node in the network as determined by the number and influence of its adjacent nodes (Lü et al. 2016). Because the eigenvector metric of a node is estimated by the eigenvector scores of adjacent nodes, this centrality metric can be interpreted as the future influence or reach of a node (Nita et al. 2016).

To identify those concepts with the highest bridging potential, we only considered those nodes with each of the three metrics belonging to the 95 th percentile. The insights offered by the three node metrics on their bridging potential were also verified against the visual position of respective nodes in the specific networks. Finally, to complement the above quantitative analysis, the authors acquired an in-depth understanding of the content of the 51 selected publications. 
Fig. 3. The semantic network for sustainability science (SS). Numbers in brackets indicate the graph density. Colors represent the following thematic clusters: (1) green: environmental change and ecosystem services; (2) yellow: resilience and vulnerability; (3) blue: knowledge production for sustainability.

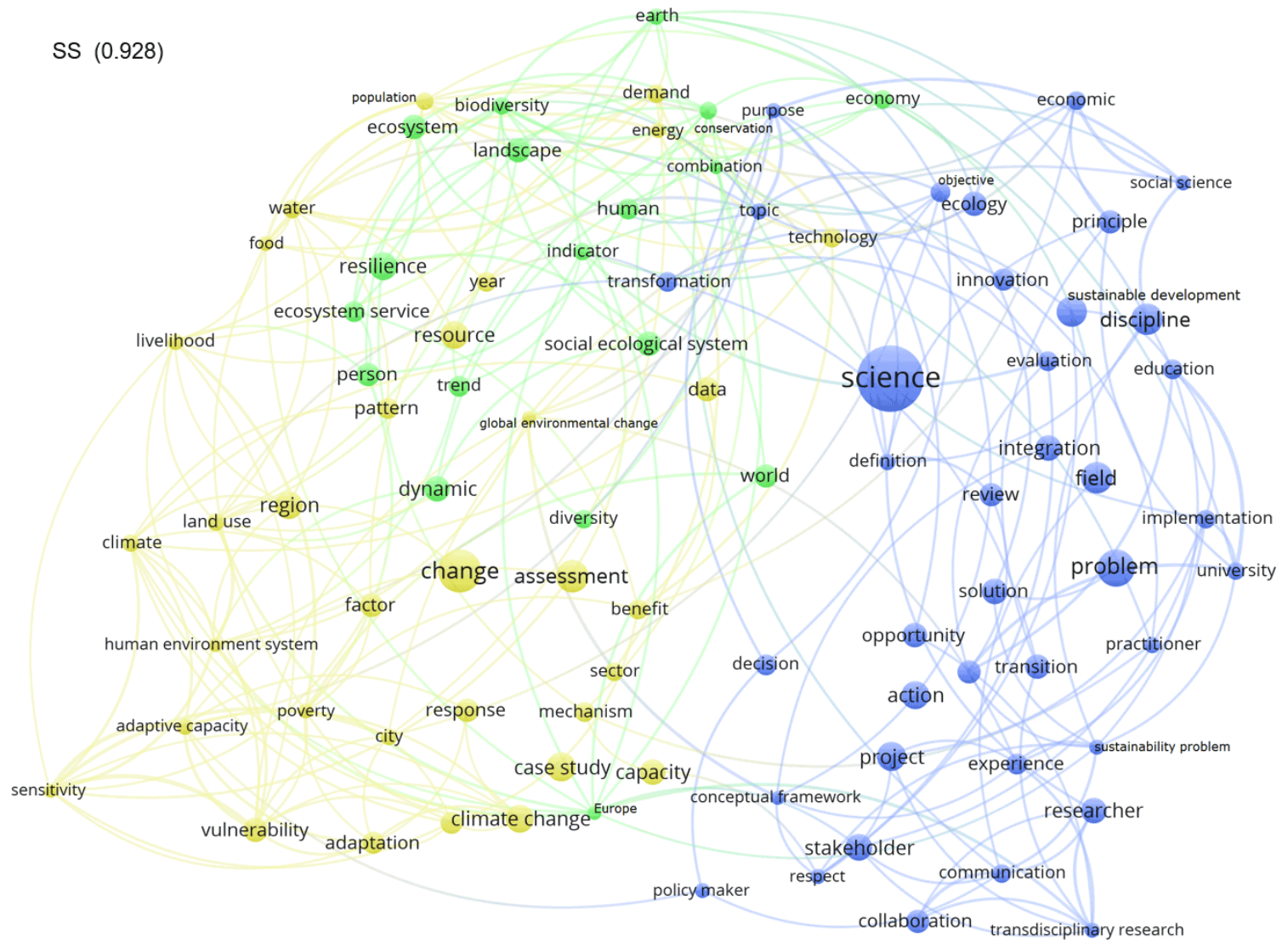

\section{RESULTS}

\section{Two interlinked pathways of sustainability transformation research}

Based on our search terms (Table 2) more papers are found under social-ecological systems research than under sustainability science (Table 3). The comparison of the graph density for the networks for SS (0.928), SES (0.996), and SS AND SES (0.995; Figs. 3-5) reveals that sustainability science and social-ecological systems research are not two distinct research pathways because the density of the grouped network (SS AND SES) is higher than the network derived for sustainability science (SS) and only slightly lower than the density of the network derived for socialecological systems research (SES). The highest density of the SES network also indicates a higher degree of coherence and interconnections compared to density of the SS network which is reflecting a more heterogeneous discourse.

\section{Bridging research pathways through transdisciplinarity}

To investigate whether transdisciplinarity acts as a bridging research mode for sustainability science and social-ecological systems research, we compared the graph densities for the networks for SS AND TD (0.580), SES AND TD (0.520), and (SS AND SES) AND TD (0.783; Figs. 6-8). The graph densities decrease compared to the networks for SS, SES, and SS AND
SES (Figs. 3-5). This indicates that the scope of studies in sustainability transformation research engaging with transdisciplinarity is broader than within research that does not engage with transdisciplinarity. The decreasing graph density signposts increasing semantic disconnection within the networks, especially in the case of SES AND TD (Fig. 7). By linking sustainability science and social-ecological systems research to transdisciplinarity, complexity and diversity in the discourse seem to increase as an expression of a broader scope because of the inclusion of sciencesociety and science-policy concerns. This diversity might be intrinsic to the transdisciplinary approach, which is problem-, solution-oriented, context dependent, case specific, and less conceptually driven by the research pathway. The graph density of the combined (SS AND SES) AND TD network is the highest, pointing to a similarity of topics investigated in a transdisciplinary mode at the intersection of sustainability science and social-ecological systems research (Fig. 8).

\section{Identifying and exploring archetypes within pathways of sustainability transformation research}

Our network analyses inductively revealed four overall clusters of sustainability transformation research, which we interpreted as sustainability transformation research archetypes (defined in Table 1). Based on their emergent theme, we labeled the four clusters: (1) environmental change and ecosystem services (in 
Fig. 4. The semantic network for social-ecological systems research (SES). Numbers in brackets indicate the graph density. Colors represent the following thematic clusters: (1) green: environmental change and ecosystem services; (2) yellow: resilience and vulnerability; (3) blue: knowledge production for sustainability; and (4) brown: governance for sustainability.

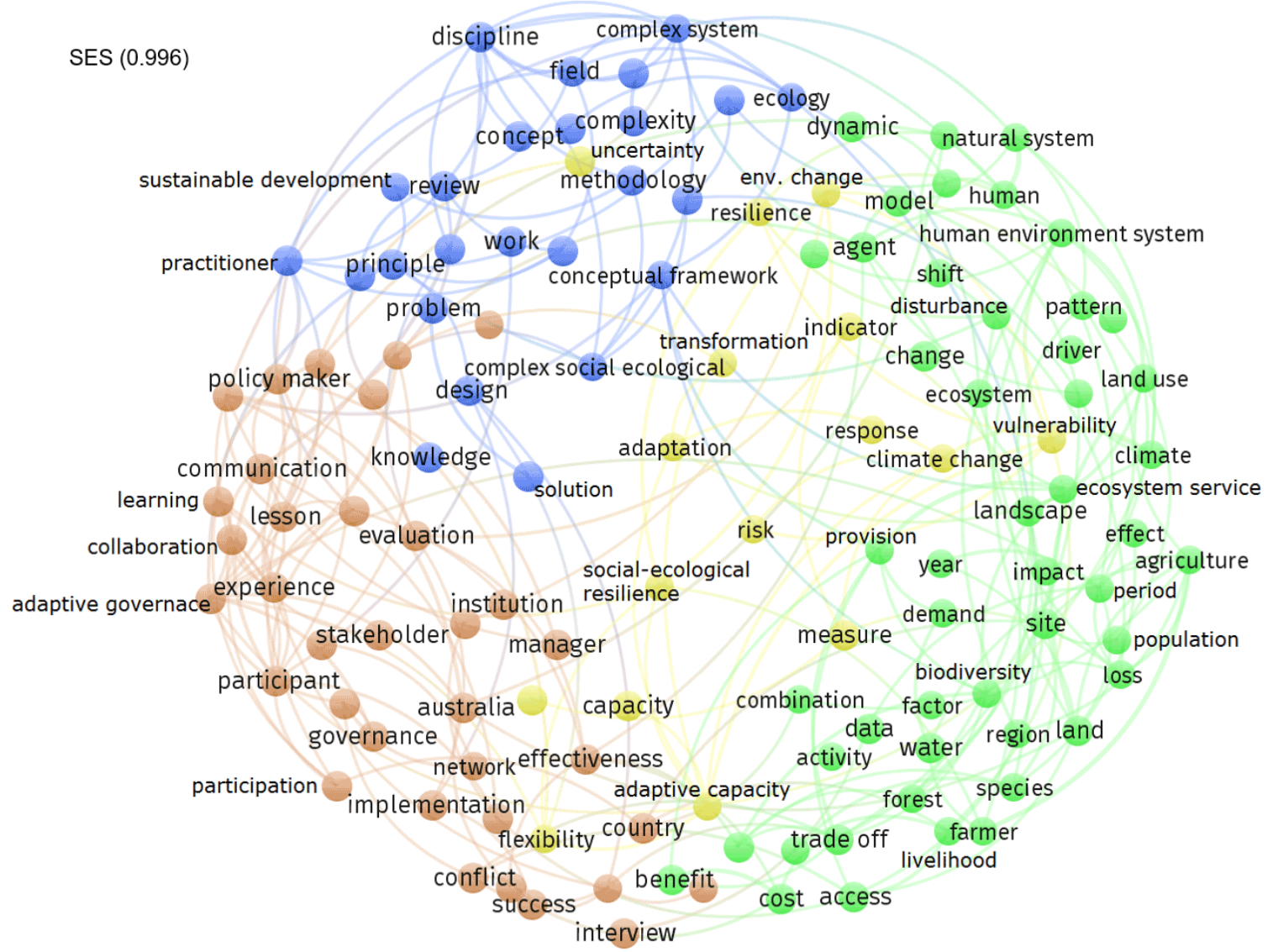

green); (2) resilience and vulnerability (in yellow); (3) knowledge production for sustainability (in blue); and (4) governance for sustainability (in brown; Figs. 3-8, Tables A3.1, A4.1). These thematic structures of leading concepts identified within sustainability science and social-ecological systems research varied across the semantic networks. For example, although these four archetypes emerged in SES and SS AND SES, SS presented only the first three clusters. Yet, it is interesting to observe that these four clusters re-emerged and together covered the thematic diversity found in almost all the different semantic networks, hence their interpretation as archetypes. Because these archetypes are not mutually exclusive, concepts may appear in more than one cluster in the different networks. An exclusive word inclusion criterion would have generated more sharply defined clusters, however with the loss of complementing terminology. Nonmutually exclusive archetypes allowed us to better interpret the clusters by comparing the node metrics of same concepts across networks.

When incorporating the link to transdisciplinarity, the semantic networks resulted in less archetypes per network. In the SES AND TD network the knowledge production cluster was missing, while in the semantic network for SS AND TD only the thematic clusters focusing on environmental change and the one focusing on knowledge production emerged. The archetype of environmental change and ecosystem services (in green) was the only one that was common across networks engaging with the transdisciplinary mode, but also across "nontransdisciplinary" networks. The lower number of thematic clusters in Figs. 6-8 compared to Figs. $3-5$ showed that linking to transdisciplinarity seemed to increase the use of different words, i.e., the diversity of nodes, to reduce the clustering potential and hence affect the emergence of well-defined archetypes of sustainability transformation research.

The identified four archetypical patterns of sustainability transformation research were also found in the semantic networks resulting from all articles citing SS and SES as well as SS AND TD and SES AND TD (Fig. A5.2). By contrast, the network built with the 51 publications under SS and SES and SS AND TD and SES AND TD (Table A1.1) only showed three archetypes as the cluster of resilience was embedded in the environmental change and governance clusters (Fig. A5.1).

Potential bridging concepts across archetypes of sustainability transformation research

The analysis of the network metrics of weighted degree, betweenness, and eigenvector centrality of nodes indicated that 
Fig. 5. The semantic network for sustainability transformation research (SS AND SES). Numbers in brackets indicate the graph density. Colors represent the following thematic clusters: (1) green: environmental change and ecosystem services; (2) yellow: resilience and vulnerability; (3) blue: knowledge production for sustainability; and (4) brown: governance for sustainability.

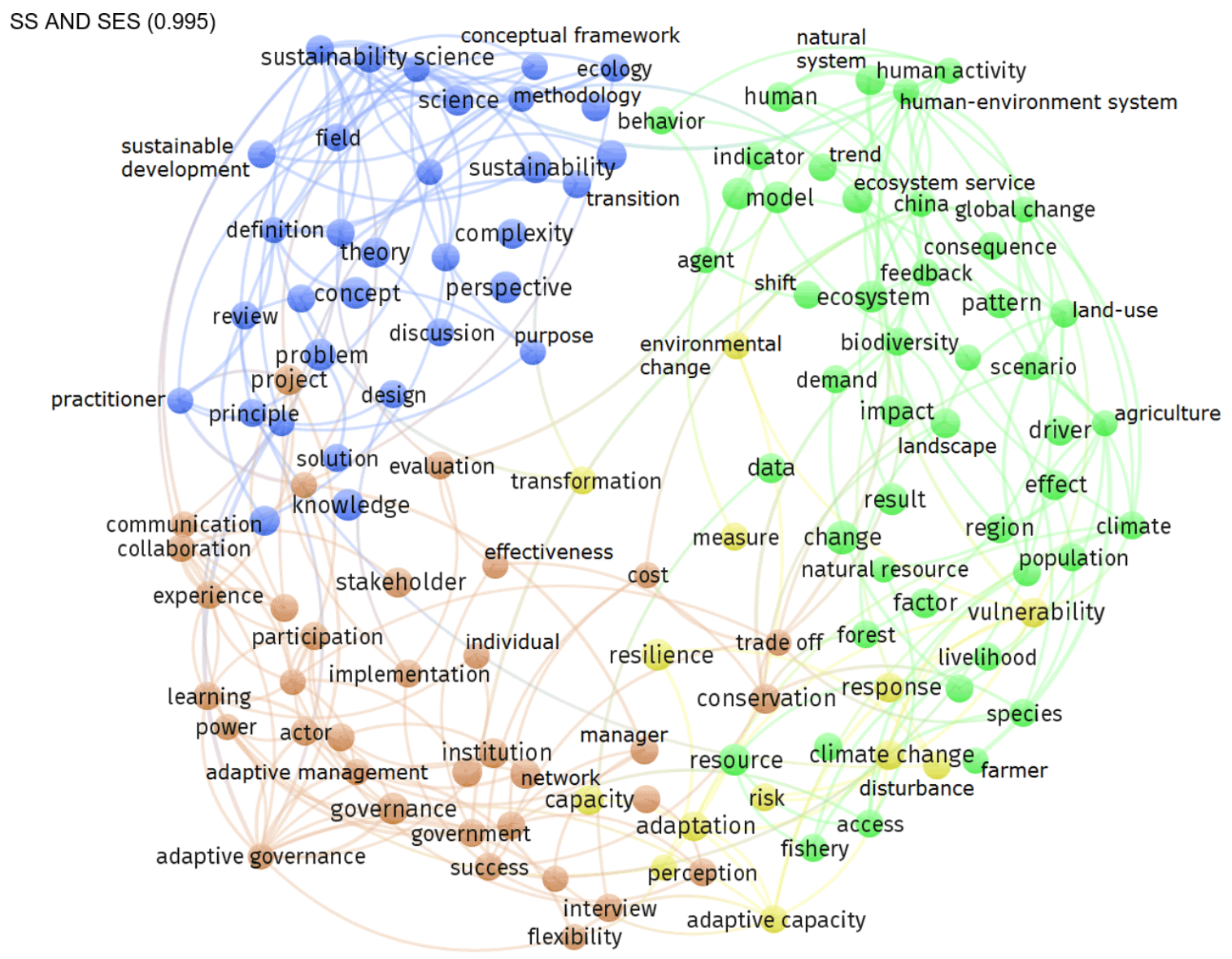

different concepts have different potentials to bridge the archetypical clusters of sustainability transformation research (Fig. 9). Regarding weighted degree, we found that all archetypes were well represented in the SES and SS AND SES networks, with concepts from the governance archetype, e.g., "participant," "communication," "stakeholder," being signified in the SES network, while concepts such as "population" and "vulnerability" belonging to the resilience archetype being emphasized in the SS semantic network (Fig. 9a). Concepts from the environmental change cluster, e.g., "change," "model," "impact," brought the highest contributions to the interconnectedness of the SS AND SES network (Fig. 9a). When considering networks that include transdisciplinarity, weighted degree values were generally lower compared to the networks not linked to transdisciplinarity, reflecting the lower individual contributions of concepts to the network interconnectedness or more equally distributed contributions to the interconnectedness of the network among nodes (Fig. 9a). Within the SS AND TD network, the clusters of knowledge production and environmental change were equally represented, with leading concepts from both archetypes, e.g., "transdisciplinary sustainability science," "review," and "principle." In the SES AND TD network, concepts from the governance cluster had again the highest weighted degree, while in the (SS AND SES) AND TD network, concepts from both the knowledge production and environmental change clusters were contributing most to interconnectedness.

In the case of betweenness, there were no clear nodes that were relevant for the interconnectedness of the SS AND SES network when the transdisciplinarity mode is not realized (Fig. 9b). When including transdisciplinarity, the above pattern (Fig. 9a) is reversed especially in the case of SES AND TD, where concepts from the resilience cluster, i.e., "ecological system," "capacity," and "participation," present the highest betweenness values (Fig. 9b). The opposite happens in the case of SS AND TD where concepts belonging to the resilience cluster decrease in their bridging importance and are surpassed by concepts belonging to the clusters of environmental change and knowledge production. Notably, nodes pertaining to the archetype of environmental change played an important connecting role across all networks with transdisciplinarity, i.e., SS AND TD, SES AND TD, and (SS AND SES) AND TD, although the concepts represented varied. Whereas concepts in the environmental change archetype refer to "methodology" and "review" in SS AND TD, in SES 
Fig. 6. The semantic network for sustainability science and transdisciplinary (SS AND TD). Numbers in brackets indicate the graph density. Colors represent the following thematic clusters: (1) green: environmental change, and ecosystem services; and (2) blue: knowledge production for sustainability.

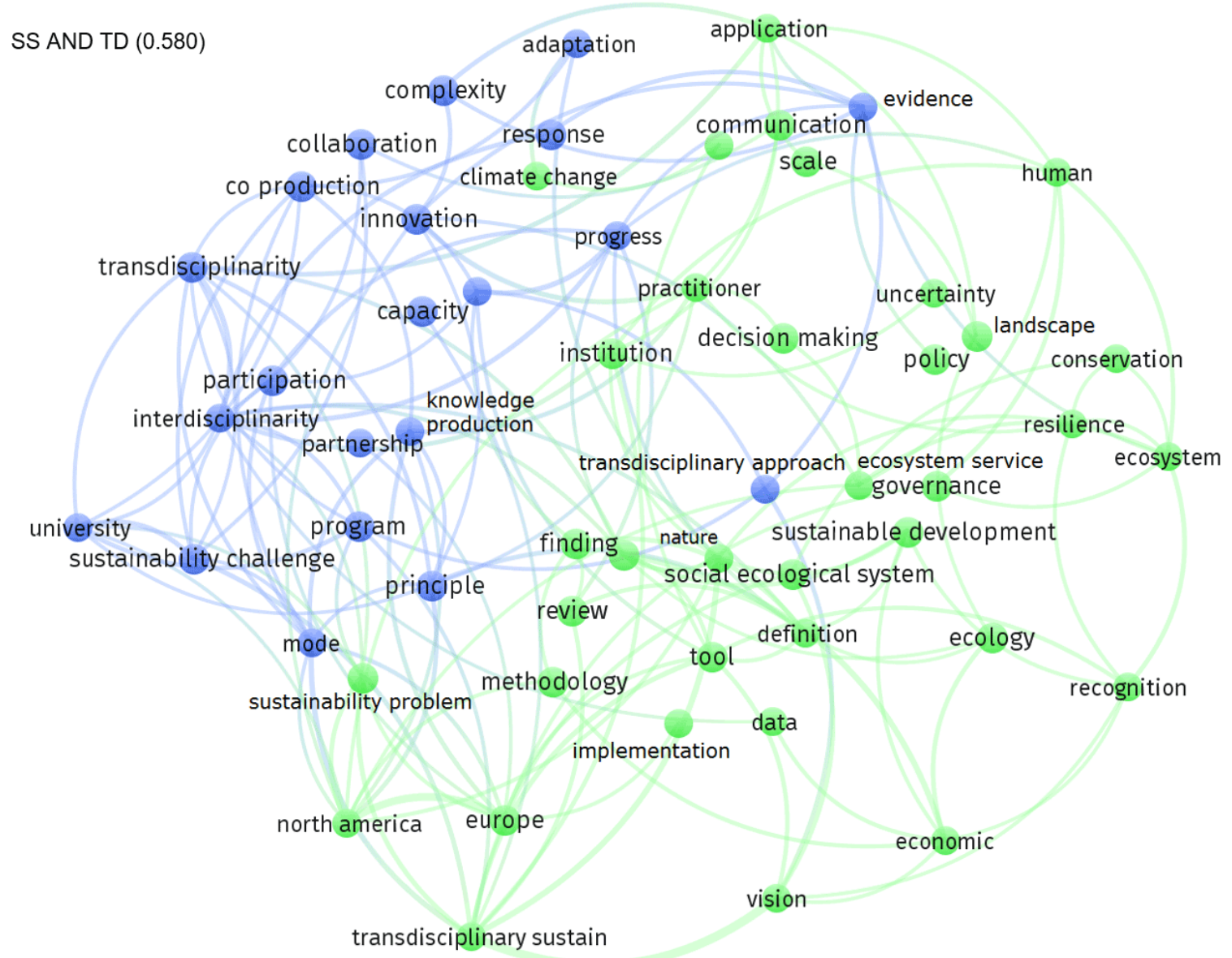

AND TD the same archetype is mostly represented by "project" and "ecosystem service," while in (SS AND SES) AND TD nodes under the archetype of environmental change targeted "policy" and "principle." Hence, foci of nodes clustered together in the same archetype reflect different orientations: toward conceptual, i.e., nonempirical, and methodological development in SS, socioenvironmental projects in SES, and policy processes in (SS AND SES) AND TD. In the latter network, the betweenness metric of the leading concept "project," which pertains to the knowledge production archetype, also points to the bridging potential of this concept. In fact, the concepts with the highest betweenness in the (SS AND SES) AND TD network are "project," "policy," "principle," and "finding," which are fundamental to the implementation and use of the solution-oriented actionable knowledge for transformation.

According to network metric results (Fig. 9), concepts with high weighted degree or betweenness values in social-ecological systems research were the ones more specific to sustainability science and vice versa. For example, although the weighted degree of "ecosystem service" was higher in the SS network, this concept is typical for social-ecological systems research. Likewise, although "principle" is often used in sustainability science because sustainability is a normative concept and the practice of sustainability science is based on design principles (e.g., Wiek et al. 2012), its weighted degree was higher in the SES network. This might be caused by the fact that title, key words, and abstract typically contain outstanding concepts that could highlight the novelty of the findings rather than terms considered as standard for a specific field. Consequently concepts such as "participant" and "stakeholder" were less likely to be mentioned in the abstracts of sustainability science papers and more likely to be mentioned in the social-ecological systems research papers (Fig. 9a).

Finally, according to the eigenvector centrality, which indicates the future reach of a node, different concepts might have a future influence in sustainability transformation research. Whereas concepts such as, "scale" (0.026), "methodology" (0.025), and "social-ecological system" (0.024) had the highest eigenvector values in the SS AND TD network, "project" (0.019), "participation" (0.018), and "ecosystem service" (0.017) had the highest eigenvector values in the SES AND TD network. Finally, "project" (0.019), "dynamic" (0.018), "policy" (0.018), and "place" $(0.018)$ had the highest eigenvector values in the (SS AND 
Fig. 7. The semantic network for social-ecological systems research and transdisciplinary (SES AND TD). Numbers in brackets indicate the graph density. Colors represent the following thematic clusters: (1) green: environmental change, and ecosystem services; (2) yellow: resilience and vulnerability; and (3) brown: governance for sustainability.

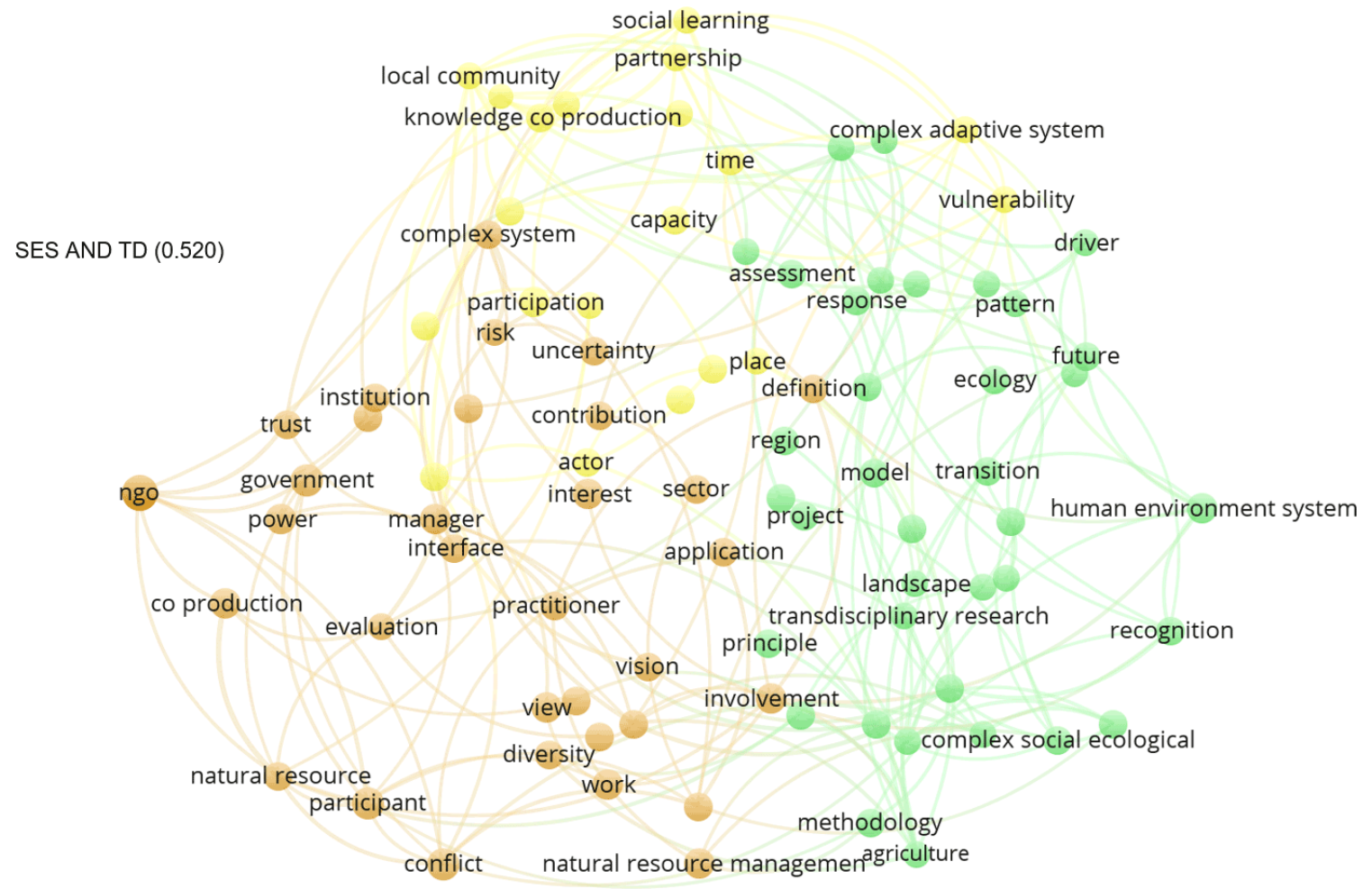

SES) AND TD network. Hence, foreseen synergies for SS and SES might revolve around place-based projects with a policy component. For example, as already foresaw by certain authors, social-ecological systems research might more strongly engage with people's participation (e.g., Oteros-Rozas et al. 2015, Balvanera et al. 2017a) and with policy frameworks (e.g., Díaz et al. 2015, Fischer et al. 2015). In parallel, sustainability science has developed more research on social-ecological systems with a place-based and policy-oriented emphasis (e.g., Redman 2014). Concurrently, the above nodes, specifically "participation," "policy," "place" are sign-posting the underlying future importance of science-society and science-policy interfaces.

\section{DISCUSSION}

\section{Sustainability science and social-ecological systems research:} linked but not connected

Exploring the discursive clusters of published literature allowed us to navigate the different understandings of knowledge and knowledge processes with regard to sustainability transformation (Binder et al. 2013, Folke et al. 2016, Partelow 2016, Partelow and Winkler 2016) of the two research pathways. Based on our core 51 publications, in the SES literature knowledge is often regarded rather as a bounded object needing to be part of decision making in order to govern transitions in the social-ecological systems toward sustainability (Robinson and Berkes 2011). Within sustainability science, the literature is often more focused on knowledge processes, practices, and spaces for collaboration (Raymond et al. 2010).

However, our results show that the two pathways are not as distinct as sometimes expected. Concepts that seem to be important because of their centrality in the network representing one research pathway are also typical of the other research pathway allowing for learning across pathways. In the SES semantic network, nodes such as "design," "knowledge," "solution," or "transformation" are graphically placed at the periphery of the clusters, but toward the center of the network, while they represent key words often used in sustainability science (Fig. 4). Similarly, when looking at the SS network, nodes such as "global environmental change," "conservation," "socialecological system," or "transformation" seem to visually mediate at the interface between different clusters (Fig. 3). Interestingly, "transformation" is the main node placed at the center of the SS AND SES network (Fig. 5). Moreover, when distilling the semantic complexity of the two transformation research pathways into four archetypes, we found the same archetypes of sustainability transformation research for SS, SES, and SS AND SES, with the exception of the governance cluster for SS. This may be due to the fact that science-policy aspects are typically framed in SES using the resilience theory (Folke et al. 2005) or Ostrom's work on institutional design for governing collective environmental resources (1990), which have a strong focus on understanding the role and functioning of governance structures. 
Fig. 8. The semantic network for sustainability transformation research with transdisciplinary ([SS AND SES] AND TD). Numbers in brackets indicate the graph density. Colors represent the following thematic clusters: (1) green: environmental change, and ecosystem services; (2) yellow: resilience and vulnerability; (3) blue: knowledge production for sustainability.

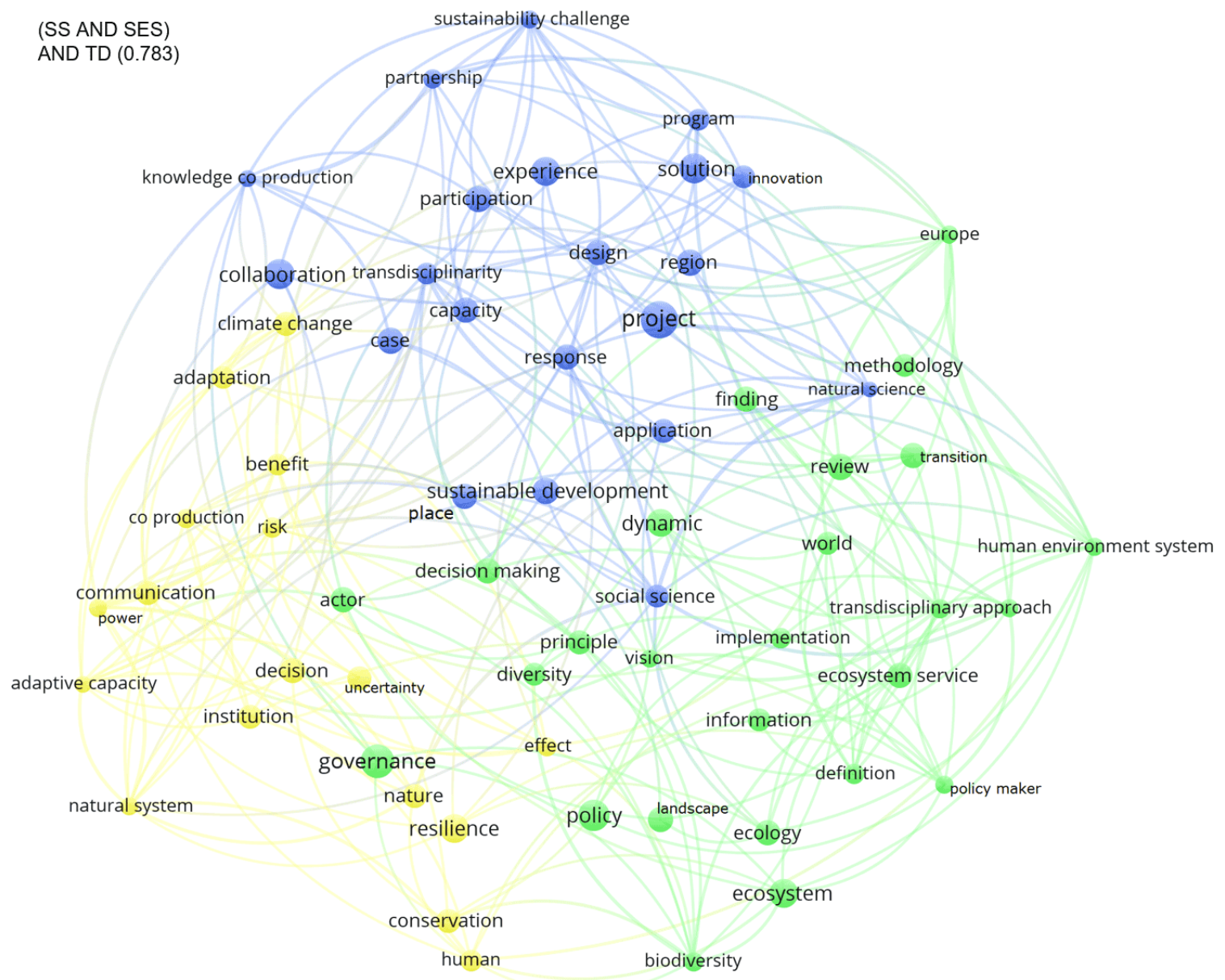

This rather descriptive character of the governance cluster in SES is due to aforementioned frameworks initially not explicitly engaging with power asymmetries as pointed out by critiques from recent literature (Olsson et al. 2015, Stone-Jovicich 2015, Nightingale 2017).

These archetypes might provide strategic stepping stones for the dialogue between the various scientific strands needed to strengthen the analytical and conceptual capacity for approaching sustainability transformations (Miller et al. 2008, Olsson et al. 2014, Pereira et al. 2018). The recurrent patterns found in the thematic structure of the networks point to a systematization based on their object of research, whether it is knowledge (the knowledge production archetype), institutions (the governance archetype), or human-nature relationships (the resilience and environmental change archetypes). To tackle complex and persistent sustainability problems, we suggest future research endeavors to effectively look into a combination of these interrelated archetypes, even if they initially depart from a single one.
Transdisciplinarity: bridging by increasing complexity

When specifically inquiring about transdisciplinarity as a potential bridging research mode, we found that sustainability science and social-ecological systems research are linked by concepts under the realm of transdisciplinarity, such as "participation," “coproduction," or "transdisciplinarity" (Fig. 9). Transdisciplinarity seems to act as a research practice that has the potential to link the pathways of social-ecological systems research and sustainability science by increasing diversity of epistemics as well as research approaches, understandings, and practices. In agreement with the problem- and solutionorientation of this research mode (Klein et al. 2001, Binder et al. 2015), the density, hence the coherence of semantic networks explicitly linked to transdisciplinarity, decreases (Figs. 6-8). In this way, transdisciplinarity seems to create a common and open arena for the two transformation research pathways to implement and operationalize their theoretical aims. As a research mode, transdisciplinarity (see Table 1) strives to move beyond abstract theoretical concepts and create actionable knowledge. Having as one key characteristic the involvement and exchange with 
Fig. 9. Leading concepts with the 5\% highest values of (a) weighted degree and (b) betweenness within the different semantic networks. Colors represent the following thematic clusters: (1) green: environmental change and ecosystem services; (2) yellow: resilience and vulnerability; (3) blue: knowledge production for sustainability; and (4) brown: governance for sustainability. The size of the nodes is relative to the centrality metrics of weighted degree and betweenness for each of the six networks. We adjusted the size of the nodes to improve visibility, e.g., network metric $=30$, in this case $30 \mathrm{x}$ smaller means size of circle $=1$. The size of the other nodes corresponds to the network metrics, e.g., network metric $=1$, size of the circle $=1$.

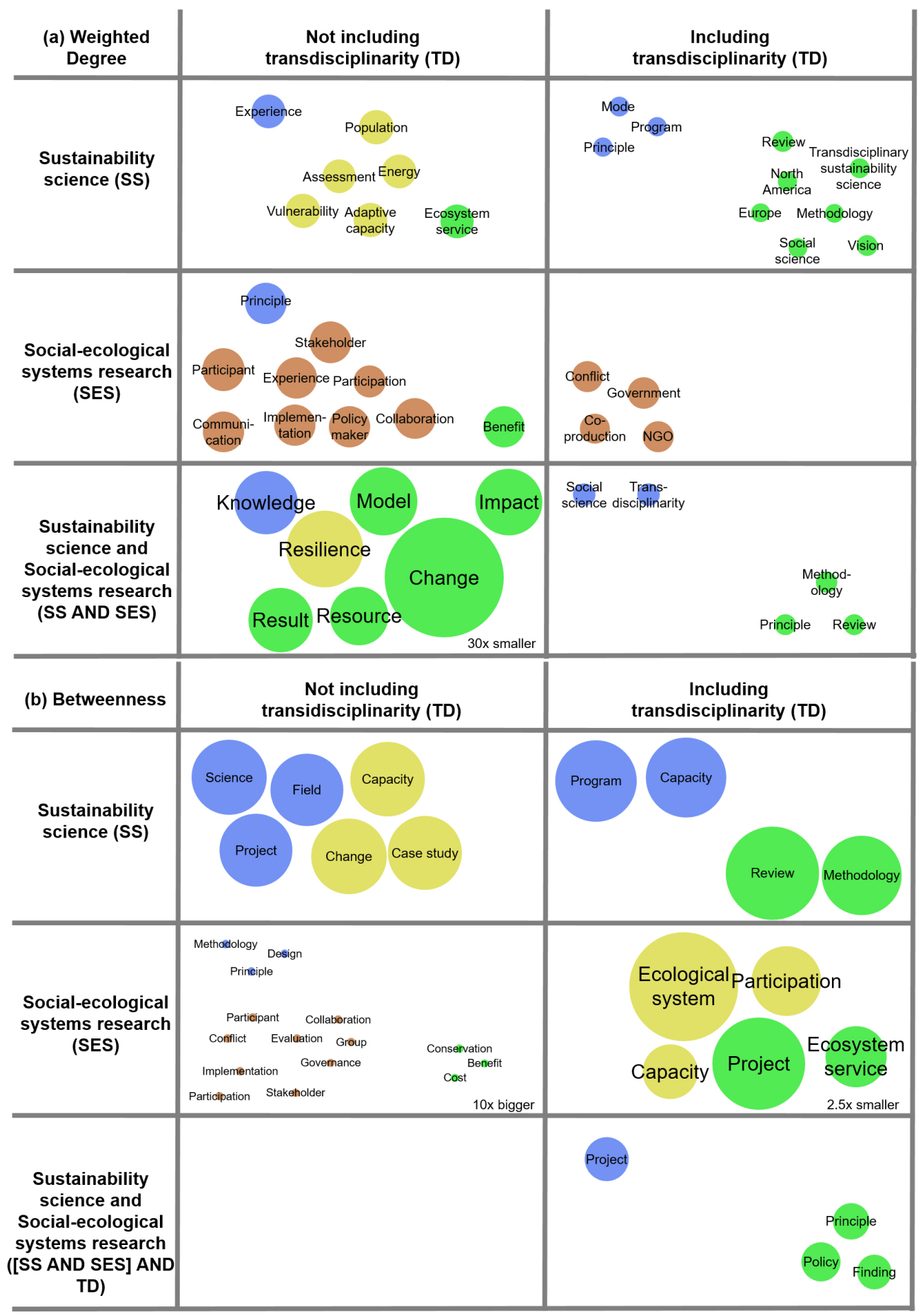


nonacademic actors in a particular context could be a second way in which transdisciplinarity can provide another meeting place for both research pathways. Both transdisciplinary socialecological systems research and transdisciplinary sustainability science recognize the context-dependency of sustainability problems sharing a concern for "place-based, long-term socialecological case studies" (Carpenter et al. 2012:136), or for "a place-based analysis of problems ... as the basis for finding effective solutions" (Spangenberg 2011:278). For example, in a review of sustainability science projects by Wiek et al. 2012, all five analyzed projects shared a place-based focus or outlined context-specific solutions. In addition, Wu (2013) defines landscape sustainability science as being an inherently placebased science.

Despite more diverse semantics in the networks engaging with transdisciplinarity, this research mode can be one of the ways to capitalize on the advancements within the two research pathways and accelerate synergies and cross fertilization (Miller et al. 2014). In fact, although at a meta and design level the transdisciplinary practice could be more homogenous (Lang et al. 2012), its various operationalizations lead to diffusion in specific fields, as shown by the lower number of identifiable clusters in the semantic networks for the literature explicitly engaging with transdisciplinarity (Figs. 6-8). Thus, the link to transdisciplinarity in the different archetypes of sustainability transformation research might not necessarily contribute to align and harmonize the practice of sustainability science and social-ecological systems research while still serving as a meeting place as described above. For example, our study showed that nodes with higher betweenness clustered under the same archetype showed a more conceptual focus in SS networks, and a less conceptual, more praxis-oriented focus in SES networks (Fig. 9b). We would even argue that this finding concurs with the fundamental problemand solution-orientation of transdisciplinarity. Rather than concretizing one specific field or pathway, this research practice has the potential to connect the different existing ones. Transdisciplinarity thus ultimately can be a relevant approach to foster the science-society relationship in both research pathways as they share the principle of knowledge coproduction (Rathwell et al. 2015, Schauppenlehner-Kloyber and Penker 2015; Figs. 68). Yet, future studies may uncover to what extent transdisciplinary pursuits pertaining to the four archetypes of sustainability transformation research genuinely engage with the fundamental desideratum of this research mode, that of reshaping the science-society interface by positioning science and society on equal footing (Hadorn et al. 2008, Seidl et al. 2013).

\section{Reinforcing the science-society interface: the role of people's participation in sustainability transformation research}

Results on network metrics highlighted concepts that can facilitate moving from collaboration deficit to knowledge coproduction and reintegration in the case of sustainability science and social-ecological systems research. For example, concepts related with action and implementation driven notions, namely "policy," "transformation," "stakeholder," "communication," or "participant" were found as bridging concepts (Fig. 9). A crosscutting notion emerging from our findings on bridging concepts is the emphasis on people and their participation. In the socialecological systems pathway, research is done together with "participants," "participation." "Stakeholder," "participant" came out as a relevant bridging concept across metrics in the networks for SES and SES AND TD, while indirectly being inferred also by "implementation," "place," or even "project" and "policy." For practitioners and researchers alike, the participation of stakeholders is relevant for implementing policies and research modes respectively (Pohl et al. 2010, Schauppenlehner-Kloyber and Penker 2015, Spangenberg et al. 2015). Regardless of the diversity of the sustainability problems, the involvement of actors outside academia, through their relationships to the "place" are a ubiquitous and universal way to operationalize a participatory and even transdisciplinary mode in both social-ecological systems research and sustainability science. Similarly, in order to foster real-world transformation, research needs to interact and engage more with the policy side of sustainability problems. Our results on the anticipated influence of certain concepts indicate that in the future, sustainability transformation research might seek to strengthen the science-policy interface. Initially working toward the surfacing, navigation, and negotiation of plural and shared understandings of relevant concepts for this interface, may result in policy impact and a better chance for implementation (see also Cvitanovic and Hobday 2018).

The context and meaning of words like "participation" or "participant" in the 51 core papers indicate that both research pathways highlight challenges associated with conducting policyrelevant participatory or collaborative research, e.g., multidisciplinary, transdisciplinary, but also ways to tackle the research-implementation disconnect (Raymond et al. 2010, Pooley et al. 2014). In the SES literature, there is an emphasis on participants as knowledge holders contributing to a rather concrete transformative outcome such as conservation practice or increased adaptive capacity (Robinson and Berkes 2011). In the SS literature, people are regarded as part of a process that in itself can be transformative through reflection and learning (Roux et al. 2010, Barth and Michelsen 2013). Future qualitative research in this direction may also bring further clarifications regarding the participation of whom, who decides who participates, and under which conditions.

\section{Limitations and methodological challenges}

Using a single search term for SS and several for SES, as well as the database of Web of Science as a single data source might explain the imbalances in the number of SS and SES papers. At the time of data extraction and subsequent analysis there was an incompatibility between the output data from Scopus and the VOSviewer software. Employed search terms for identifying transdisciplinary literature were relatively narrow (Table 2) and we only considered English literature. The resulting 51 core selected papers (Table A1.1) are predominantly conceptual, advancing theoretical frameworks or recommendations for new research directions, containing few empirical studies. There are nine overlapping publications in Table A1.1, with five papers overlapping specifically for the SS and SES networks. The semantic networks performed on title, abstract, and key words does not consider words in their full context of utilization in the different papers. We therefore caution that our findings need to be interpreted in the light of the main assumption of this type of analysis, i.e., that individual words could be used as indicators of discursive realties within whole research fields, but do not entirely represent these. 
The implications of above caveats are twofold. First, publications may be populated with certain jargon terms that may not accurately reflect the real level of engagement with these terms in practice. For example, publications using "policy," "implementation," or "transdisciplinary" may report the findings of fundamental research investigating these topics, rather than present findings of transformative original projects or case studies carried out toward implementation or policy change. It is possible that some of the papers included in our study have less connection to transdisciplinarity than indicated in the text. Second, the bridging potential of the highlighted nodes as indicated by the values of different network metrics should be regarded with caution because the same terms might have different understandings, epistemological sources, and contexts of application within the two research pathways. For example, the word "principle" is used in the SES literature in relation to Ostrom's design principle for common pool resource institutions (Folke et al. 2005) or in relation to the precautionary principle (Adger 2006). In the SS literature it typically refers to the design principles of transdisciplinary research (Lang et al. 2012). In both research pathways however, "principle" is used with the general understanding of fundamental guidance for behaviors and beliefs (Weichselgartner and Kelman 2015), and specifically with reference to sustainability principles (Wiek et al. 2012). Moreover, a network analysis is inherently interested in the relationships between nodes and the whole network configuration, as much as in the individual nodes and their roles in relation to the others. For example, although same words may appear in the different networks, their node metrics are different across the networks. Finally, a qualitative context analysis would have enabled us to further expand on the variable meaning of the same words that appear in different networks or clusters. Future research directions could uncover more nuanced conceptual debates in the sustainability transformation research and transdisciplinary literature.

\section{CONCLUSION}

In this paper, we introduced a multimethods approach of archetype analysis to explore synergies and common concepts between the research pathways of social-ecological systems research and sustainability science. The archetype analysis based on semantic networks and clusters as well as different network metrics allowed to identify archetypes of sustainability transformation research. Even though this might look as an abstract and conceptual endeavor at a first glance, our results indicate the potential of such analyses to enable the identification of synergies between different research discourses for an accelerated contribution that science can make to a desirable societal transformative change.

Our results also indicated that sustainability science and socialecological systems research are already linked in meeting the goal of fostering transformation toward sustainability, but only partly connected in the realm of transdisciplinary practice. Yet, the diversity indicated by the latter research mode is not necessarily an indication for a conceptual weakness, but seems to be partly caused by the inherent problem- and solution-oriented approach underlying its application. Continuously exploring and developing those interlinkages, as well as their specificities, without the purpose of aligning them, can help the two pathways to further utilize their full potential. For example, some of the bridging concepts revealed by our study seem to converge toward the importance of involving people in the research framing and process. Through their relationship to a place, bounded often as a social-ecological construct, stakeholders and people at large play an essential role in sustainability transformation research. Problem- and solution-oriented research approaches actively involving actors outside academia, even if differently labeled and not explicitly following principles of transdisciplinarity, are thus reconfirmed as a suited way to open research to the complexity and uncertainty connected to sustainability transformations. Therefore, consolidating and further fostering these approaches seem to have the potential to serve as a bridging research mode across the two transformation research pathways also connecting science, society, and policy. In so doing, linking the two pathways and leveraging the potential of transdisciplinarity and similar research modes can further strengthen their common purpose to foster sustainability transformations.

Responses to this article can be read online at: http://www.ecologyandsociety.org/issues/responses. $\mathrm{php} / 11332$

\section{Acknowledgments:}

This research was supported by the Volkswagen Stiftung and the Niedersächsischen Ministeriums für Wissenschaft und Kultur funded project "Leverage Points for Sustainable Transformations: Institutions, People and Knowledge*\#8221; [Grant Number A112269]. The authors are grateful to two anonymous reviewers who greatly improved the manuscript with their observations.

\section{LITERATURE CITED}

Abson, D. J., H. von Wehrden, S. Baumgärtner, J. Fischer, J. Hanspach, W. Härdtle, H. Heinrichs, A. M. Klein, D. J. Lang, P. Martens, and D. Walmsley. 2014. Ecosystem services as a boundary object for sustainability. Ecological Economics 103:29-37. https://doi.org/10.1016/j.ecolecon.2014.04.012

Adger, W. N. 2006. Vulnerability. Global Environmental Change 16(3):268-281. https://doi.org/10.1016/j.gloenvcha.2006.02.006

Armitage, D., C. Béné, A. T. Charles, D. Johnson, and E. H. Allison. 2012. The interplay of well-being and resilience in applying a social- ecological perspective. Ecology and Society 17 (4):15. https://doi.org/10.5751/ES-04940-170415

Baggio, J. A., K. Brown, and D. Hellebrandt. 2015. Boundary object or bridging concept? A citation network analysis of resilience. Ecology and Society 20(2):2. https://doi.org/10.5751/ ES-07484-200202

Balvanera, P., R. Calderón-Contreras, A. J. Castro, M. R. FelipeLucia, I. R. Geijzendorffer, S. Jacobs, B. Martín-López, U. Arbieu, C. I. Speranza, B. Locatelli, N. P. Harguindeguy, I. R. Mercado, M. J. Spierenburg, A. Vallet, L. Lynes, and L. Gillson. $2017 b$. Interconnected place-based social-ecological research can inform global sustainability. Current Opinion in Environmental Sustainability 29:1-7. https://doi.org/10.1016/j.cosust.2017.09.005 
Balvanera, P., T. M. Daw, T. Gardner, B. Martin-Lopez, A. Norstrom, C. Ifejika Speranza, M. Speirenburg, E. M. Bennett, M. Farfan, M. Hamann, J. N. Kittinger, T. Luthe, M. Maass, G. D. Peterson, and G. Pérez-Verdin. 2017a. Key features for more successful place-based sustainability research on social-ecological systems: a Programme on Ecosystem Change and Society (PECS) perspective. Ecology and Society 22(1):14. https://doi. org/10.5751/es-08826-220114

Barth, M., and G. Michelsen. 2013. Learning for change: an educational contribution to sustainability science. Sustainability Science 8(1):103-119. https://doi.org/10.1007/s11625-012-0181-5

Berkes, F., J. Colding, and C. Folke, editors. 2003. Navigating social-ecological systems: building resilience for complexity and change. Cambridge University Press, Cambridge, UK. https://doi. org/10.1017/CBO9780511541957

Bettencourt, L. M. A., and J. Kaur. 2011. Evolution and structure of sustainability science. Proceedings of the National Academy of Sciences 108(49):19540-19545. https://doi.org/10.1073/pnas.1102712108

Binder, C. R., I. Absenger-Helmli, and T. Schilling. 2015. The reality of transdisciplinarity: a framework-based self-reflection from science and practice leaders. Sustainability Science 10 (4):545-562. https://doi.org/10.1007/s11625-015-0328-2

Binder, C. R., J. Hinkel, P. W. G. Bots, and C. Pahl-Wostl. 2013. Comparison of frameworks for analyzing social-ecological systems. Ecology and Society 18(4):26. https://doi.org/10.5751/ ES-05551-180426

Borgatti, S. P., and M. G. Everett. 1997. Network analysis of 2mode data. Social Networks 19(3):243-269. https://doi. org/10.1016/s0378-8733(96)00301-2

Brandt, P., A. Ernst, F. Gralla, C. Luederitz, D. J. Lang, J. Newig, F. Reinert, D. J. Abson, and H. Von Wehrden. 2013. A review of transdisciplinary research in sustainability science. Ecological Economics 92:1-15. https://doi.org/10.1016/j.ecolecon.2013.04.008

Carpenter, S. R., C. Folke, A. Norström, O. Olsson, L. Schultz, B. Agarwal, P. Balvanera, B. Campbell, J. C. Castilla, W. Cramer, R. DeFries, P. Eyzaguirre, T. P. Hughes, S. Polasky, Z. Sanusi, R. Scholes, and M. Spierenburg. 2012. Program on ecosystem change and society: an international research strategy for integrated social-ecological systems. Current Opinion in Environmental Sustainability 4:134-138. https://doi.org/10.1016/j.cosust.2012.01.001

Certomà, C., F. Corsini, and F. Rizzi. 2015. Crowdsourcing urban sustainability. Data, people and technologies in participatory governance. Futures 74:93-106. https://doi.org/10.1016/j. futures.2014.11.006

Clark, W. C., and N. M. Dickson. 2003. Sustainability science: the emerging research program. Proceedings of the National Academy of Sciences 100(14):8059-8061. https://doi.org/10.1073/ pnas. 1231333100

Clauset, A., M. E. J. Newman, and C. Moore. 2004. Finding community structure in very large networks. Physical Review E 70:066111. https://doi.org/10.1103/PhysRevE.70.066111

Colding, J., and S. Barthel. 2019. Exploring the social-ecological systems discourse 20 years later. Ecology and Society 24(1):2. https://doi.org/10.5751/es-10598-240102
Cornell, S., F. Berkhout, W. Tuinstra, J. D. Tabara, J. Jager, I. Chabay, B. de Wit, R. Langlais, D. Mills, P. Moll, I. M. Otto, A. Petersen, C. Pohl, and L. van Kerkhoff. 2013. Opening up knowledge systems for better responses to global environmental change. Environmental Science and Policy 28:60-70. https://doi. org/10.1016/j.envsci.2012.11.008

Cote, M., and A. J. Nightingale. 2012. Resilience thinking meets social theory: situating social change in socio-ecological systems (SES) research. Progress in Human Geography 36:475-489. https:// doi.org/10.1177/0309132511425708

Cvitanovic, C., and A. J. Hobday. 2018. Building optimism at the environmental science-policy-practice interface through the study of bright spots. Nature Communications 9:3466. https://doi. org/10.1038/s41467-018-05977-w

Díaz, S., S. Demissew, J. Carabias, C. Joly, M. Lonsdale, N. Ash, A. Larigauderie, J. R. Adhikari, S. Arico, A. Báldi, A. Bartuska, I. A. Baste, A. Bilgin, E. Brondizio, K. M. A. Chan, V. E. Figueroa, A. Duraiappah, M. Fischer, R. Hill, T. Koetz, P. Leadley, P. Lyver, G. M. Mace, B. Martin-Lopez, M. Okumura, D. Pacheco, U. Pascual, E. S. Pérez, B. Reyers, E. Roth, O. Saito, R. J. Scholes, N. Sharma, H. Tallis, R. Thaman, R. Watson, T. Yahara, Z. A. Hamid, C. Akosim, Y. Al-Hafedh, R. Allahverdiyev, E. Amankwah, T. S. Asah, Z. Asfaw, G. Bartus, A. L. Brooks, J. Caillaux, G. Dalle, D. Darnaedi, A. Driver, G. Erpul, P. EscobarEyzaguirre, P. Failler, A. M. M. Fouda, B. Fu, H. Gundimeda, S. Hashimoto, F. Homer, S. Lavorel, G. Lichtenstein, W. A. Mala, W. Mandivenyi, P. Matczak, C. Mbizvo, M. Mehrdadi, J. P. Metzger, J. B. Mikissa, H. Moller, H. A. Mooney, P. Mumby, H. Nagendra, C. Nesshover, A. A. Oteng-Yeboah, G. Pataki, M. Roué, J. Rubis, M. Schultz, P. Smith, R. Sumaila, K. Takeuchi, S. Thomas, M. Verma, Y. Yeo-Chang, and D. Zlatanova. 2015. The IPBES Conceptual Framework - connecting nature and people. Current Opinion in Environmental Sustainability 14:1-16. https:// doi.org/10.1016/j.cosust.2014.11.002

Eisenack, K. 2012. Archetypes of adaptation to climate change. Pages 107-122 in M. Glaser, B. M. W. Ratter, and M. Welp, editors. Human-nature interactions in the Anthropocene: potentials of social-ecological systems analysis. Routledge, New York, New York, USA. https://doi.org/10.4324/9780203123195

Eisenack, K., M. Luedeke, and J. Kropp. 2006. Construction of archetypes as a formal method to analyze social-ecological systems. Proceedings of the Institutional Dimensions of Global Environmental Change Synthesis Conference, Bali, Indonesia. [online] URL: https://uol.de/fileadmin/user upload/wire/fachgebiete/ envdev/download/arch-eisenack3.pdf

Fazey, I., N. Schäpke, G. Caniglia, J. Patterson, J. Hultman, B. van Mierlo, F. Säwe, A. Wiek, J. Wittmayer, P. Aldunce, H. Al Waer, N. Battacharya, H. Bradbury, E. Carmen, J. Colvin, C. Cvitanovic, M. D'Souza, M. Gopel, B. Goldstein, T. Hämäläinen, G. Harper, T. Henfry, A. Hodgson, M. S. Howden, A. Kerr, M. Klaes, C. Lyon, G. Midgley, S. Moser, N. Mukherjee, K. Müller, K. O'Brien, D. A. O'Connell, P. Olsson, G. Page, M. S. Reed, B. Searle, G. Silvestri, V. Spaiser, T. Strasser, P. Tschakert, N. UribeCalvo, S. Waddell, J. Rao-Williams, R. Wise, R. Wolstenholme, M. Woods, and C. Wyborn. 2018. Ten essentials for actionoriented and second order energy transitions, transformations and climate change research. Energy Research \& Social Science 40:54-70. https://doi.org/10.1016/j.erss.2017.11.026 
Fischer, J., T. A. Gardner, E. M. Bennett, P. Balvanera, R. Biggs, S. Carpenter, T. Daw, C. Folke, R. Hill, T. P. Hughes, T. Luthe, M. Maass, M. Meacham, A. V. Norstrom, G. Peterson, C. Queiroz, R. Seppelt, M. Spierenburg, and J. Tenhunen. 2015. Advancing sustainability through mainstreaming a socialecological systems perspective. Current Opinion in Environmental Sustainability 14:144-149. https://doi.org/10.1016/j.cosust.2015.06.002

Folke, C. 2006. Resilience: the emergence of a perspective for social-ecological systems analyses. Global Environmental Change 16(3):253-267. https://doi.org/10.1016/j.gloenvcha.2006.04.002

Folke, C., R. Biggs, A. V. Norström, B. Reyers, and J. Rockström. 2016. Social-ecological resilience and biosphere-based sustainability science. Ecology and Society 21(3):41. https://doi.org/10.5751/ ES-08748-210341

Folke, C., T. Hahn, P. Olsson, and J. Norberg. 2005. Adaptive governance of social-ecological systems. Annual Review of Environment and Resources 30(1):441-473. https://doi.org/10.1146/ annurev.energy.30.050504.144511

Freeman, L. C. 1978-1979. Centrality in social networks conceptual clarification. Social Networks 1(3):215-239. https:// doi.org/10.1016/0378-8733(78)90021-7

Gunderson, L. H., and C. S. Holling. 2002. Panarchy: understanding transformations in human and natural systems. Island, Washington, D.C., USA.

Hadorn, G. H., H. Hoffmann-Riem, S. Biber-Klemm, W. Grossenbacher-Mansuy, D. Joye, C. Pohl, U. Wiesmann, and E. Zemp, editors. 2008. Handbook of transdisciplinary research. Springer, Dordrecht, The Netherlands. https://doi. org/10.1007/978-1-4020-6699-3

Hartel, T., N. Fagerholm, M. Torralba, Á. Balázsi, and T. Plieninger. 2018. Forum: social-ecological system archetypes for European rangelands. Rangeland Ecology \& Management 71 (5):536-544. https://doi.org/10.1016/j.rama.2018.03.006

Hölscher, K., J. M. Wittmayer, and D. Loorbach. 2018. Transition versus transformation: what's the difference? Environmental Innovation and Societal Transitions 27:1-3. https://doi. org/10.1016/j.eist.2017.10.007

Jahn, T., M. Bergmann, and F. Keil. 2012. Transdisciplinarity: between mainstreaming and marginalization. Ecological Economics 79:1-10. https://doi.org/10.1016/j.ecolecon.2012.04.017

Jerneck, A., L. Olsson, B. Ness, S. Anderberg, M. Baier, E. Clark, T. Hickler, A. Hornborg, A. Kronsell, E. Lövbrand, and J. Persson. 2011. Structuring sustainability science. Sustainability Science 6(1):69-82. https://doi.org/10.1007/s11625-010-0117-x

Kajikawa, Y., F. Tacoa, and K. Yamaguchi. 2014. Sustainability science: the changing landscape of sustainability research. Sustainability Science 9(4):431-438. https://doi.org/10.1007/ $\underline{\text { s11625-014-0244-X }}$

Kates, R. W., W. C. Clark, R. Corell, J. M. Hall, C. C. Jaeger, I. Lowe, J. J. Mccarthy, H. J. Schellnhuber, B. Bolin, N. M. Dickson, S. Faucheux, G. C. Gallopin, A. Grübler, B. Huntley, J. Jäger, N. S. Jodha, R. E. Kasperson, A. Mabogunje, P. Matson, H. Mooney, B. Moore III, T. O'Riordan, and U. Svedin. 2001. Sustainability science. Science 292(5517):641-642. https://doi.org/10.1126/ $\underline{\text { science. } 1059386}$
Klein, J. T., R. Häberli, R. W. Scholz, W. Grossenbacher-Mansuy, A. Bill, and M. Welti, editors. 2001. Transdisciplinarity: joint problem solving among science, technology, and society: an effective way for managing complexity. Birkhäuser Verlag, Basel, Switzerland. https://doi.org/10.1007/978-3-0348-8419-8

Lang, D. J., A. Wiek, M. Bergmann, M. Stauffacher, P. Martens, P. Moll, M. Swilling, and C. J. Thomas. 2012. Transdisciplinary research in sustainability science: practice, principles, and challenges. Sustainability Science 7:25-43. https://doi.org/10.1007/ $\underline{\text { s11625-011-0149-X }}$

Larigauderie, A., and H. A. Mooney. 2010. The intergovernmental science-policy platform on biodiversity and ecosystem services: moving a step closer to an IPCC-like mechanism for biodiversity. Current Opinion in Environmental Sustainability 2(1-2):9-14. https://doi.org/10.1016/j.cosust.2010.02.006

Leslie, H. M., X. Basurto, M. Nenadovic, L. Sievanen, K. C. Cavanaugh, J. J. Cota-Nieto, B. E. Erisman, E. Finkbeiner, G. Hinojosa-Arango, M. Moreno-Báez, S. Nagavarapu, S. M. W. Reddy, A. Sánchez-Rodríguez, K. Siegel, J. J. UlibarriaValenzuela, A. H. Weaver, and O. Aburto-Oropeza. 2015. Operationalizing the social-ecological systems framework to assess sustainability. Proceedings of the National Academy of Sciences 112(19):5979-5984. https://doi.org/10.1073/pnas.1414640112

Liehr, S., J. Röhrig, M. Mehring, and T. Kluge. 2017. How the social-ecological systems concept can guide transdisciplinary research and implementation: addressing water challenges in central northern Namibia. Sustainability 9(7):1109. https://doi. org/10.3390/su9071109

Locatelli, B., S. Lavorel, S. Sloan, U. Tappeiner, and D. Geneletti. 2017. Characteristic trajectories of ecosystem services in mountains. Frontiers in Ecology and the Environment 15 (3):150-159. https://doi.org/10.1002/fee.1470

Loorbach, D., N. Frantzeskaki, and F. Avelino. 2017. Sustainability transitions research: transforming science and practice for societal change. Annual Review of Environment and Resources 42:599-626. https://doi.org/10.1146/annurevenviron-102014-021340

Lü, L., D. Chen, X.-L. Ren, Q.-M. Zhang, Y.-C. Zhang, and T. Zhou. 2016. Vital nodes identification in complex networks. Physics Reports 650:1-63. https://doi.org/10.1016/j.physrep.2016.06.007

Mauser, W., G. Klepper, M. Rice, B. S. Schmalzbauer, H. Hackmann, R. Leemans, and H. Moore. 2013. Transdisciplinary global change research: the co-creation of knowledge for sustainability. Current Opinion in Environmental Sustainability 5 (3-4):420-431. https://doi.org/10.1016/j.cosust.2013.07.001

Max-Neef, M. A. 2005. Foundations of transdisciplinarity. Ecological Economics 53(1):5-16. https://doi.org/10.1016/j. ecolecon.2005.01.014

Miller, T. R. 2013. Constructing sustainability science: emerging perspectives and research trajectories. Sustainability Science 8 (2):279-293. https://doi.org/10.1007/s11625-012-0180-6

Miller, T. R., T. D. Baird, C. M. Littlefield, G. Kofinas, F. Chapin, III, and C. L. Redman. 2008. Epistemological pluralism: reorganizing interdisciplinary research. Ecology And Society 13 (2):46. https://doi.org/10.5751/ES-02671-130246 
Miller, T. R., A. Wiek, D. Sarewitz, J. Robinson, L. Olsson, D. Kriebel, and D. Loorbach. 2014. The future of sustainability science: a solutions-oriented research agenda. Sustainability Science 9:239-246. https://doi.org/10.1007/s11625-013-0224-6

Newig, J., P. Derwort, and N. W. Jager. 2019. Sustainability through institutional failure and decline? Archetypes of productive pathways. Ecology and Society 24(1):18. https://doi. org/10.5751/ES-10700-240118

Newman, M. E. J. 2006. Modularity and community structure in networks. Proceedings of the National Academy of Sciences 103 (23):8577-8582. https://doi.org/10.1073/pnas.0601602103

Newman, M. E. J., and M. Girvan. 2004. Finding and evaluating community structure in networks. Physical Review E 69:026113. https://doi.org/10.1103/PhysRevE.69.026113

Nightingale, A. J. 2017. Power and politics in climate change adaptation efforts: struggles over authority and recognition in the context of political instability. Geoforum 84:11-20. https://doi. org/10.1016/j.geoforum.2017.05.011

Nita, A., L. Rozylowicz, S. Manolache, C. M. Ciocănea, I. V. Miu, and V. D. Popescu. 2016. Collaboration networks in applied conservation projects across Europe. PLoS ONE 11(10): e0164503. https://doi.org/10.1371/journal.pone.0164503

Olsson, L., A. Jerneck, H. Thoren, J. Persson, and D. O. Byrne. 2015. Why resilience is unappealing to social science: theoretical and empirical investigations of the scientific use of resilience. Science Advances 1(4):e1400217. https://doi.org/10.1126/sciadv.1400217

Olsson, P., V. Galaz, and W. J. Boonstra. 2014. Sustainability transformations: a resilience perspective. Ecology and Society 19 (4):1. https://doi.org/10.5751/ES-06799-190401

Ostrom, E. 1990. Governing the commons: the evaluation of institutions and collective action. Cambridge University Press, Cambridge, UK.

Ostrom, E. 2009. A general framework for analyzing sustainability of social-ecological systems. Science 325 (5939):419-422. https://doi.org/10.1126/science.1172133

Oteros-Rozas, E., B. Martín-López, T. Daw, E. L. Bohensky, J. Butler, R. Hill, J. Martin-Ortega, A. Quinlan, F. Ravera, I. RuizMallén, M. Thyresson, J. Mistry, I. Palomo, G. D. Peterson, T. Plieninger, K. A. Waylen, D. Beach, I. C. Bohnet, M. Hamann, J. Hanspach, K. Hubacek, S. Lavorel, and S. Vilardy. 2015. Participatory scenario-planning in place-based social-ecological research: insights and experiences from 23 case studies. Ecology and Society 20(4):32. https://doi.org/10.5751/es-07985-200432

Partelow, S. 2016. Coevolving Ostrom's social-ecological systems (SES) framework and sustainability science: four key co-benefits. Sustainability Science 11(3):399-410. https://doi.org/10.1007/ $\underline{\text { s11625-015-0351-3 }}$

Partelow, S. 2018. A review of the social-ecological systems framework: applications, methods, modifications, and challenges. Ecology and Society 23(4):36. https://doi.org/10.5751/ES-10594-230436

Partelow, S., and K. J. Winkler. 2016. Interlinking ecosystem services and Ostrom's framework through orientation in sustainability research Ecology and Society 21(3):27. https://doi. org/10.5751/es-08524-210327
Pereira, L. M., T. Karpouzoglou, N. Frantzeskaki, and P. Olsson. 2018. Designing transformative spaces for sustainability in socialecological systems. Ecology and Society 23(4):32. https://doi. org/10.5751/ES-10607-230432

Pohl, C., S. Rist, A. Zimmermann, P. Fry, G. S. Gurung, F. Schneider, C. I. Speranza, B. Kiteme, S. Boillat, E. Serrano, G. H. Hadorn, and U. Wiesmann. 2010. Researchers' roles in knowledge co-production: experience from sustainability research in Kenya, Switzerland, Bolivia and Nepal. Science \& Public Policy 37(4):267-281. https://doi.org/10.3152/030234210X496628

Pooley, S. P., J. A. Mendelsohn, and E. J. Milner-Gulland. 2014. Hunting down the chimera of multiple disciplinarity in conservation science. Conservation Biology 28(1):22-32. https:// doi.org/10.1111/cobi.12183

Rathwell, K. J., D. Armitage, and F. Berkes. 2015. Bridging knowledge systems to enhance governance of the environmental commons: a typology of settings. International Journal of the Commons 9(2):851-880. https://doi.org/10.18352/ijc.584

Raymond, C. M., I. Fazey, M. S. Reed, L. C. Stringer, G. M. Robinson, and A. C. Evely. 2010. Integrating local and scientific knowledge for environmental management. Journal of Environmental Management 91:1766-1777. https://doi.org/10.1016/ j.jenvman.2010.03.023

Redman, C. L. 2014. Should sustainability and resilience be combined or remain distinct pursuits? Ecology and Society 19 (2):37. https://doi.org/10.5751/es-06390-190237

Robins, G. 2015. Doing social network research: network-based research design for social scientists. SAGE, London, UK.

Robinson, L. W., and F. Berkes. 2011. Multi-level participation for building adaptive capacity: formal agency-community interactions in northern Kenya. Global Environmental Change 21 (4):1185-1194. https://doi.org/10.1016/j.gloenvcha.2011.07.012

Roux, D. J., R. J. Stirzaker, C. M. Breen, E. C. Lefroy, and H. P. Cresswell. 2010. Framework for participative reflection on the accomplishment of transdisciplinary research programs. Environmental Science and Policy 13(8):733-741. https://doi. org/10.1016/i.envsci.2010.08.002

Schauppenlehner-Kloyber, E., and M. Penker. 2015. Managing group processes in transdisciplinary future studies: how to facilitate social learning and capacity building for self-organised action towards sustainable urban development? Futures 65:57-71. https://doi.org/10.1016/j.futures.2014.08.012

Scholz, R. W., and G. Steiner. 2015. The real type and ideal type of transdisciplinary processes: part I-theoretical foundations. Sustainability Science 10(4):527-544. https://doi.org/10.1007/ s11625-015-0326-4

Sedighi, M. 2016. Application of word co-occurrence analysis method in mapping of the scientific fields (case study: the field of Informetrics). Library Review 65(1/2):52-64. https://doi. org/10.1108/LR-07-2015-0075

Seidl, R., F. S. Brand, M. Stauffacher, P. Krütli, Q. B. Le, A. Spörri, G. Meylan, C. Moser, M. B. González, and R. W. Scholz. 2013. Science with society in the Anthropocene. Ambio 42(1):5-12. https://doi.org/10.1007/s13280-012-0363-5 
Spangenberg, J. H. 2011. Sustainability science: a review, an analysis and some empirical lessons. Environmental Conservation 38(3):275-287. https://doi.org/10.1017/S0376892911000270

Spangenberg, J. H., C. Görg, and J. Settele. 2015. Stakeholder involvement in ESS research and governance: between conceptual ambition and practical experiences - risks, challenges and tested tools. Ecosystem Services 16:201-211. https://doi.org/10.1016/j. ecoser.2015.10.006

Stone-Jovicich, S. 2015. Probing the interfaces between the social sciences and social-ecological resilience: insights from integrative and hybrid perspectives in the social sciences. Ecology and Society 20(2):25. https://doi.org/10.5751/ES-07347-200225

van Atteveldt, W. 2008. Semantic network analysis: techniques for extracting, representing, and querying media content. BookSurge, Charleston, South Carolina, USA.

van der Hel, S. 2018. Science for change: a survey on the normative and political dimensions of global sustainability research. Global Environmental Change 52:248-258. https://doi.org/10.1016/j. gloenvcha.2018.07.005

van Eck, N. J., and L. Waltman. 2010. Software survey: VOSviewer, a computer program for bibliometric mapping. Scientometrics 84(2):523-538. https://doi.org/10.1007/s11192-009-0146-3

Waltman, L., N. J. van Eck, and E. C. M. Noyons. 2010. A unified approach to mapping and clustering of bibliometric networks. Journal of Informetrics 4(4):629-635. https://doi.org/10.1016/j. joi.2010.07.002

Wasserman, S., and K. Faust. 1994. Social network analysis: methods and applications. Cambridge University Press, Cambridge, UK. https://doi.org/10.1017/CBO9780511815478

Weichselgartner, J., and I. Kelman. 2015. Geographies of resilience: challenges and opportunities of a descriptive concept. Progress in Human Geography 39(3):249-267. https://doi. org/10.1177/0309132513518834

West, S. 2016. Meaning and action in sustainability science: interpretive approaches for social-ecological systems research. Stockholm Resilience Centre, Stockholm University, Stockholm, Sweden.

Wiek, A., and D. J. Lang. 2016. Transformational sustainability research methodology. Pages 31-41 in H. Heinrichs, P. Martens, G. Michelsen, and A. Wiek, editors. Sustainability science: an introduction. Springer, Dordrecht, The Netherlands. https://doi. org/10.1007/978-94-017-7242-6 3

Wiek, A., B. Ness, P. Schweizer-Ries, F. S. Brand, and F. Farioli. 2012. From complex systems analysis to transformational change: a comparative appraisal of sustainability science projects. Sustainability Science 7(S1):5-24. https://doi.org/10.1007/ s11625-011-0148-y

Wu, J. 2013. Landscape sustainability science: ecosystem services and human well-being in changing landscapes. Landscape Ecology 28(6):999-1023. https://doi.org/10.1007/s10980-013-9894-9

Yan, E., Y. Ding, and E. K. Jacob. 2012. Overlaying communities and topics: an analysis on publication networks. Scientometrics 90(2):499-513. https://doi.org/10.1007/s11192-011-0531-6 
Table A1.1. The core papers resulting from the literature search and selection. Titles with “*” indicate overlapping papers.

\begin{tabular}{|c|c|c|c|}
\hline \multicolumn{2}{|l|}{ SS } & \multicolumn{2}{|l|}{ SES } \\
\hline $\begin{array}{l}\text { Vulnerability. Global Environmental } \\
\text { Change 16(3):268-281. }\end{array}$ & Adger, W. Neil. 2006* & $\begin{array}{l}\text { A safe operating space for humanity. } \\
\text { Nature } 461: 472-475 \text {. }\end{array}$ & $\begin{array}{l}\text { Rockstrom, Johan; Steffen, Will; Noone, Kevin; Persson, Asa; } \\
\text { Chapin, F. Stuart, III; Lambin, Eric F.; Lenton, Timothy M.; } \\
\text { Scheffer, Marten; Folke, Carl; Schellnhuber, Hans Joachim; } \\
\text { Nykvist, Bjorn; de Wit, Cynthia A.; Hughes, Terry; van der } \\
\text { Leeuw, Sander; Rodhe, Henning; Sorlin, Sverker; Snyder, Peter } \\
\text { K.; Costanza, Robert; Svedin, Uno; Falkenmark, Malin; } \\
\text { Karlberg, Louise; Corell, Robert W.; Fabry, Victoria J.; Hansen, } \\
\text { James; Walker, Brian; Liverman, Diana; Richardson, Katherine; } \\
\text { Crutzen, Paul; Foley, Jonathan A. 2009 }\end{array}$ \\
\hline $\begin{array}{l}\text { Science for managing ecosystem services: } \\
\text { Beyond the Millennium Ecosystem } \\
\text { Assessment. PNAS 106(5):1305-1312. }\end{array}$ & $\begin{array}{l}\text { Carpenter, Stephen R.; Mooney, Harold A.; Agard, John; } \\
\text { Capistrano, Doris; DeFries, Ruth S.; Diaz, Sandra; Dietz, } \\
\text { Thomas; Duraiappah, Anantha K.; Oteng-Yeboah, Alfred; } \\
\text { Pereira, Henrique Miguel; Perrings, Charles; Reid, Walter V.; } \\
\text { Sarukhan, Jose; Scholes, Robert J.; Whyte, Anne. 2009* }\end{array}$ & $\begin{array}{l}\text { A General Framework for Analyzing } \\
\text { Sustainability of Social-Ecological Systems. } \\
\text { Science 325(5939):419-422. }\end{array}$ & Ostrom, Elinor. 2009 \\
\hline $\begin{array}{l}\text { Resilience, adaptability and transformability } \\
\text { in social-ecological systems. Ecology And } \\
\text { Society 9(2). }\end{array}$ & $\begin{array}{l}\text { Walker, Brian; Holling, CS; Carpenter, Stephen R; Kinzig, Ann. } \\
\text { 2004* }\end{array}$ & $\begin{array}{l}\text { Resilience: The emergence of a perspective } \\
\text { for social-ecological systems analyses. } \\
\text { Global Environmental Change 16(3):253- } \\
267 .\end{array}$ & Folke, Carl. 2006 \\
\hline $\begin{array}{l}\text { A framework for vulnerability analysis in } \\
\text { sustainability science. } P N A S 100(14): 8074- \\
8079 .\end{array}$ & $\begin{array}{l}\text { Turner, BL; Kasperson, Roger E; Matson, Pamela A; McCarthy, } \\
\text { James J; Corell, Robert W; Christensen, Lindsey; Eckley, } \\
\text { Noelle; Kasperson, Jeanne X; Luers, Amy; Martello, Marybeth } \\
\text { L; Polsky, Colin; Pulsipher, Alexander; Schiller, Andrew. 2003* }\end{array}$ & $\begin{array}{l}\text { Adaptive governance of social-ecological } \\
\text { systems. Annual Review of Environment } \\
\text { and Resources 30(1):441-473. }\end{array}$ & Folke, Carl; Hahn, Thomas; Olsson, Per; Norberg, Jon. 2005 \\
\hline $\begin{array}{l}\text { A diagnostic approach for going beyond } \\
\text { panaceas. PNAS 104(39):15181-7. }\end{array}$ & Ostrom, Elinor. 2007* & $\begin{array}{l}\text { Vulnerability. Global Environmental } \\
\text { Change 16(3):268-281. }\end{array}$ & Adger, W. Neil. 2006* \\
\hline $\begin{array}{l}\text { Global desertification: Building a science } \\
\text { for dryland development. Science } \\
316(5826): 847-851 \text {. }\end{array}$ & $\begin{array}{l}\text { Reynolds, James F.; Stafford Smith, D. Mark; Lambin, Eric F.; } \\
\text { Turner, B. L.; Mortimore, Michael; Batterbury, Simon P. J.; } \\
\text { Downing, Thomas E.; Dowlatabadi, Hadi; Fernandez, Roberto J.; } \\
\text { Herrick, Jeffrey E.; Huber-Sannwald, Elisabeth; Jiang, Hong; } \\
\text { Leemans, Rik; Lynam, Tim; Maestre, Fernando T.; Ayarza, } \\
\text { Miguel; Walker, Brian. } 2007\end{array}$ & $\begin{array}{l}\text { Complexity of coupled human and natural } \\
\text { systems. Science 317(5844):1513-1516. }\end{array}$ & $\begin{array}{l}\text { Liu, Jianguo; Dietz, Thomas; Carpenter, Stephen R.; Alberti, } \\
\text { Marina; Folke, Carl; Moran, Emilio; Pell, Alice N.; Deadman, } \\
\text { Peter; Kratz, Timothy; Lubchenco, Jane; Ostrom, Elinor; } \\
\text { Ouyang, Zhiyun; Provencher, William; Redman, Charles L.; } \\
\text { Schneider, Stephen H.; Taylor, William W. } 2007\end{array}$ \\
\hline $\begin{array}{l}\text { Environment and development - } \\
\text { Sustainability science. Science 292:641- } \\
642 .\end{array}$ & $\begin{array}{l}\text { Kates, Robert W; Clark, William C; Corell, Robert; Hall, J. } \\
\text { Michael; Jaeger, Carlo C; Lowe, Ian; McCarthy, James J; } \\
\text { Schellnhuber, Hans J; Bolin, Bert; Dickson, Nancy M; Faucheux, } \\
\text { Sylvie; Gallopin, Gilberto C; Grubler, Arnulf; Huntley, Brian; } \\
\text { Jager, Jill; Jodha, Narpat S; Kasperson, Roger E; Mabogunje, } \\
\text { Akin; Matson, Pamela; Mooney, Harald; Moore, Berrien; } \\
\text { O'Riordan, Timothy; Svedin, Uno. } 2001\end{array}$ & $\begin{array}{l}\text { Science for managing ecosystem services: } \\
\text { Beyond the Millennium Ecosystem } \\
\text { Assessment. PNAS 106(5):1305-1312. }\end{array}$ & $\begin{array}{l}\text { Carpenter, Stephen R.; Mooney, Harold A.; Agard, John; } \\
\text { Capistrano, Doris; DeFries, Ruth S.; Diaz, Sandra; Dietz, } \\
\text { Thomas; Duraiappah, Anantha K.; Oteng-Yeboah, Alfred; } \\
\text { Pereira, Henrique Miguel; Perrings, Charles; Reid, Walter V.; } \\
\text { Sarukhan, Jose; Scholes, Robert J.; Whyte, Anne. 2009* }\end{array}$ \\
\hline $\begin{array}{l}\text { Humid tropical forest clearing from } 2000 \text { to } \\
2005 \text { quantified by using multitemporal and } \\
\text { multiresolution remotely sensed data. PNAS } \\
\text { 105(27):9439-44 }\end{array}$ & $\begin{array}{l}\text { Hansen, Matthew C.; Stehman, Stephen V.; Potapov, Peter V.; } \\
\text { Loveland, Thomas R.; Townshend, John R. G.; DeFries, Ruth S.; } \\
\text { Pittman, Kyle W.; Arunarwati, Belinda; Stolle, Fred; Steininger, } \\
\text { Marc K.; Carroll, Mark; DiMiceli, Charlene. } 2008\end{array}$ & $\begin{array}{l}\text { Resilience, adaptability and } \\
\text { transformability in social-ecological } \\
\text { systems. Ecology And Society 9(2). }\end{array}$ & Walker, Brian; Holling, CS; Carpenter, SR; Kinzig, A. 2004* \\
\hline $\begin{array}{l}\text { Transdisciplinary research in sustainability } \\
\text { science: practice, principles, and challenges. } \\
\text { Sustainability Science 7:25-43. }\end{array}$ & $\begin{array}{l}\text { Lang, Daniel J.; Wiek, Arnim; Bergmann, Matthias; Stauffacher, } \\
\text { Michael; Martens, Pim; Moll, Peter; Swilling, Mark; Thomas, } \\
\text { Christopher J.2012* }\end{array}$ & $\begin{array}{l}\text { A framework for vulnerability analysis in } \\
\text { sustainability science. PNAS 100(14):8074- } \\
8079 .\end{array}$ & $\begin{array}{l}\text { Turner, BL; Kasperson, Roger E; Matson, Pamela A; McCarthy, } \\
\text { James J; Corell, Robert W; Christensen, Lindsey; Eckley, } \\
\text { Noelle; Kasperson, Jeanne X; Luers, Amy; Martello, Marybeth } \\
\text { L; Polsky, Colin; Pulsipher, Alexander; Schiller, Andrew. 2003* }\end{array}$ \\
\hline
\end{tabular}




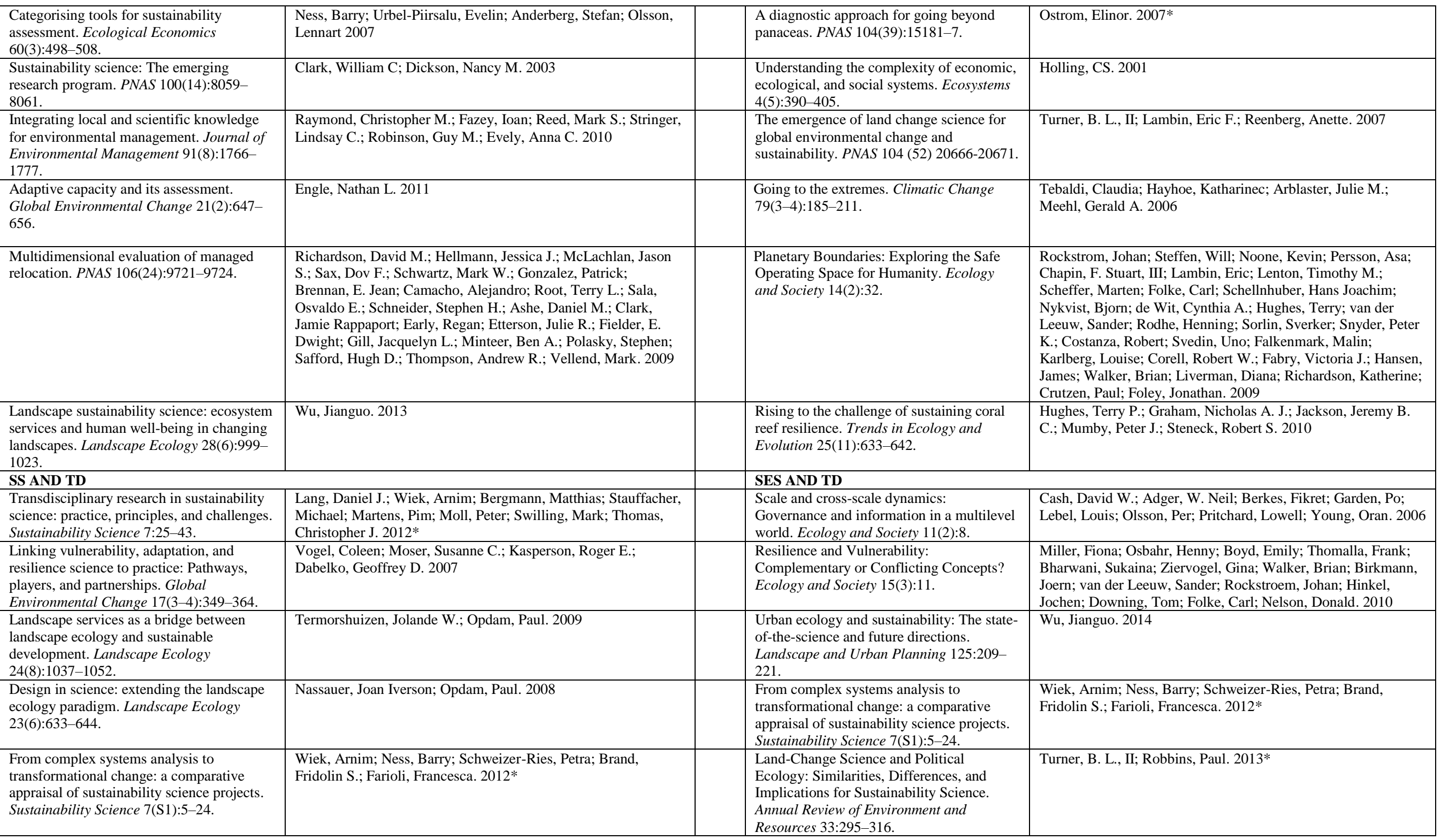




\begin{tabular}{|c|c|c|c|}
\hline $\begin{array}{l}\text { Structuring sustainability science. } \\
\text { Sustainability Science 6(1):69-82. }\end{array}$ & $\begin{array}{l}\text { Jerneck, Anne; Olsson, Lennart; Ness, Barry; Anderberg, Stefan; } \\
\text { Baier, Matthias; Clark, Eric; Hickler, Thomas; Hornborg, Alf; } \\
\text { Kronsell, Annica; Lovbrand, Eva; Persson, Johannes. } 2011\end{array}$ & $\begin{array}{l}\text { Implementing ecosystem-based } \\
\text { management: evolution or revolution? Fish } \\
\text { and Fisheries 13(4):465-476. }\end{array}$ & Berkes, Fikret. 2012 \\
\hline $\begin{array}{l}\text { A review of transdisciplinary research in } \\
\text { sustainability science. Ecological } \\
\text { Economics } 92 \text { (August): } 1-15 \text {. }\end{array}$ & $\begin{array}{l}\text { Brandt, Patric; Ernst, Anna; Gralla, Fabienne; Luederitz, } \\
\text { Christopher; Lang, Daniel J.; Newig, Jens; Reinert, Florian; } \\
\text { Abson, David J.; von Wehrden, Henrik. } 2013\end{array}$ & $\begin{array}{l}\text { Geographies of resilience: Challenges and } \\
\text { opportunities of a descriptive concept. } \\
\text { Progress in Human Geography 39(3):249- } \\
267 .\end{array}$ & Weichselgartner, Juergen; Kelman, Ilan. 2015 \\
\hline $\begin{array}{l}\text { Sustainability science: a review, an analysis } \\
\text { and some empirical lessons. Environmental } \\
\text { Conservation 38(3):275-287. }\end{array}$ & Spangenberg, Joachim H. 2011 & $\begin{array}{l}\text { Disentangling intangible social-ecological } \\
\text { systems. Global Environmental Change } \\
\text { 22(2):430-439. }\end{array}$ & Bodin, Orjan; Tengo, Maria. 2012 \\
\hline $\begin{array}{l}\text { Transdisciplinary global change research: } \\
\text { the co-creation of knowledge for } \\
\text { sustainability. Current Opinion in } \\
\text { Environmental Sustainability } 5(3-4): 420 \\
\text { 431. }\end{array}$ & $\begin{array}{l}\text { Mauser, Wolfram; Klepper, Gernot; Rice, Martin; Schmalzbauer, } \\
\text { Bettina Susanne; Hackmann, Heide; Leemans, Rik; Moore, } \\
\text { Howard. } 2013\end{array}$ & $\begin{array}{l}\text { Environmental flows and water governance: } \\
\text { managing sustainable water uses. Current } \\
\text { Opinion in Environmental Sustainability } \\
\text { 5(3-4):341-351. }\end{array}$ & $\begin{array}{l}\text { Pahl-Wostl, Claudia; Arthington, Angela; Bogardi, Janos; Bunn, } \\
\text { Stuart E.; Hoff, Holger; Lebel, Louis; Nikitina, Elena; Palmer, } \\
\text { Margaret; Poff, LeRoy N.; Richards, Keith; Schluter, Maja; } \\
\text { Schulze, Roland; St-Hilaire, Andre; Tharme, Rebecca; Tockner, } \\
\text { Klement; Tsegai, Daniel. } 2013\end{array}$ \\
\hline $\begin{array}{l}\text { Land-Change Science and Political } \\
\text { Ecology: Similarities, Differences, and } \\
\text { Implications for Sustainability Science. } \\
\text { Annual Review of Environment and } \\
\text { Resources 33:295-316. }\end{array}$ & Turner, B. L., II; Robbins, Paul. 2013* & $\begin{array}{l}\text { Rethinking the Galapagos Islands as a } \\
\text { Complex Social-Ecological System: } \\
\text { Implications for Conservation and } \\
\text { Management. Ecology and Society } \\
\text { 13(2):13. }\end{array}$ & $\begin{array}{l}\text { Gonzalez, Jose A.; Montes, Carlos; Rodriguez, Jose; Tapia, } \\
\text { Washington. 2008* }\end{array}$ \\
\hline $\begin{array}{l}\text { Establishing sustainability science in higher } \\
\text { education institutions: towards an } \\
\text { integration of academic development, } \\
\text { institutionalization, and stakeholder } \\
\text { collaborations. Sustainability Science } \\
\text { 7(SUPPL. 1):101-113. }\end{array}$ & $\begin{array}{l}\text { Yarime, Masaru; Trencher, Gregory; Mino, Takashi; Scholz, } \\
\text { Roland W.; Olsson, Lennart; Ness, Barry; Frantzeskaki, Niki; } \\
\text { Rotmans, Jan. } 2012\end{array}$ & $\begin{array}{l}\text { Multi-level participation for building } \\
\text { adaptive capacity: Formal agency- } \\
\text { community interactions in northern Kenya. } \\
\text { Global Environmental Change 21(4):1185- } \\
1194 \text {. }\end{array}$ & Robinson, Lance W.; Berkes, Fikret. 2011 \\
\hline $\begin{array}{l}\text { Framework for participative reflection on } \\
\text { the accomplishment of transdisciplinary } \\
\text { research programs. Environmental Science } \\
\text { and Policy 13(8):733-741. }\end{array}$ & $\begin{array}{l}\text { Roux, Dirk J.; Stirzaker, Richard J.; Breen, Charles M.; Lefroy, } \\
\text { E. C.; Cresswell, Hamish P. } 2010\end{array}$ & $\begin{array}{l}\text { Program on ecosystem change and society: } \\
\text { an international research strategy for } \\
\text { integrated social-ecological systems. } \\
\text { Current Opinion in Environmental } \\
\text { Sustainability 4(1):134-138. }\end{array}$ & $\begin{array}{l}\text { Carpenter, Stephen R.; Folke, Carl; Norstrom, Albert; Olsson, } \\
\text { Olof; Schultz, Lisen; Agarwal, Bina; Balvanera, Patricia; } \\
\text { Campbell, Bruce; Carlos Castilla, Juan; Cramer, Wolfgang; } \\
\text { DeFries, Ruth; Eyzaguirre, Pablo; Hughes, Terry P.; Polasky, } \\
\text { Stephen; Sanusi, Zainal; Scholes, Robert; Spierenburg, Marja. } \\
2012\end{array}$ \\
\hline $\begin{array}{l}\text { Learning for change: an educational } \\
\text { contribution to sustainability science. } \\
\text { Sustainability Science 8(1):103-119. }\end{array}$ & Barth, Matthias; Michelsen, Gerd. 2013 & $\begin{array}{l}\text { Hunting Down the Chimera of Multiple } \\
\text { Disciplinarity in Conservation Science. } \\
\text { Conservation Biology 28(1):22-32. }\end{array}$ & $\begin{array}{l}\text { Pooley, Simon P.; Mendelsohn, J. Andrew; Milner-Gulland, E. } \\
\text { J. } 2014\end{array}$ \\
\hline $\begin{array}{l}\text { Progress in sustainability science: lessons } \\
\text { learnt from current methodologies for } \\
\text { sustainability assessment: Part } 1 . \\
\text { International Journal of Life Cycle } \\
\text { Assessment } 18(9): 1653-1672 \text {. }\end{array}$ & Sala, Serenella; Farioli, Francesca; Zamagni, Alessandra. 2013 & $\begin{array}{l}\text { Science with Society in the Anthropocene. } \\
\text { Ambio 42(1):5-12. }\end{array}$ & $\begin{array}{l}\text { Seidl, Roman; Brand, Fridolin Simon; Stauffacher, Michael; } \\
\text { Kruetli, Pius; Le, Quang Bao; Spoerri, Andy; Meylan, Gregoire; } \\
\text { Moser, Corinne; Gonzalez, Monica Berger; Scholz, Roland } \\
\text { Werner. } 2013\end{array}$ \\
\hline $\begin{array}{l}\text { Rethinking the Galapagos Islands as a } \\
\text { Complex Social-Ecological System: } \\
\text { Implications for Conservation and } \\
\text { Management. Ecology and Society 13(2):13. }\end{array}$ & $\begin{array}{l}\text { Gonzalez, Jose A.; Montes, Carlos; Rodriguez, Jose; Tapia, } \\
\text { Washington. 2008* }\end{array}$ & $\begin{array}{l}\text { The Interplay of Well-being and Resilience } \\
\text { in Applying a Social-Ecological } \\
\text { Perspective. Ecology and Society 17(4):5. }\end{array}$ & $\begin{array}{l}\text { Armitage, Derek; Bene, Chris; Charles, Anthony T.; Johnson, } \\
\text { Derek; Allison, Edward H. } 2012\end{array}$ \\
\hline
\end{tabular}


Table A2.1. List of words (presented in alphabetical order) that were excluded for the semantic network analysis.

\begin{tabular}{|l|}
\hline Words \\
\hline addition \\
aim \\
area \\
article \\
core \\
expectation \\
face \\
fund \\
funder \\
interpretation \\
limit \\
order \\
practice \\
proposal \\
range \\
rate \\
regard \\
research \\
results \\
scholar \\
self \\
set \\
spite \\
step \\
study \\
term \\
total \\
type \\
\hline
\end{tabular}


Table A3.1. List of words (presented in alphabetical order) comprising each cluster in the SS, SES, and SS AND SES semantic networks.

Clusters

Environmental

change and

ecosystem services

(in green)
SS

ability
biodiversity
capacity
combination
conservation
diversity
dynamic
earth
ecology
ecosystem
ecosystem service
Europe
human
indicator
landscape
life
mechanism
person
resilience
social-ecological system
time
trend
world

\section{SES}

access

activity

agent

agriculture

benefit

biodiversity

change

climate

combination

conservation

cost

data

demand

disturbance

driver

dynamic

ecosystem

ecosystem service

effect

factor

farmer

feedback

fishery

forest

human

human environment system

impact

land

land use

landscape

livelihood

loss

model

natural system

pattern

period

population

provision

region

scenario

shift

site

space

species

threshold

\section{SS AND SES}

access

agent

agriculture

behavior

biodiversity

change

climate

consequence

data

demand

driver

dynamic

ecosystem

ecosystem service

effect

factor

farmer

feedback

fishery

forest

global change

human

human activity

human environment

system

impact

indicator

influence

land

land use

landscape

livelihood

model

natural resource

natural system

pattern

population

region

resource

result

scenario

shift

site

species

trend

water 


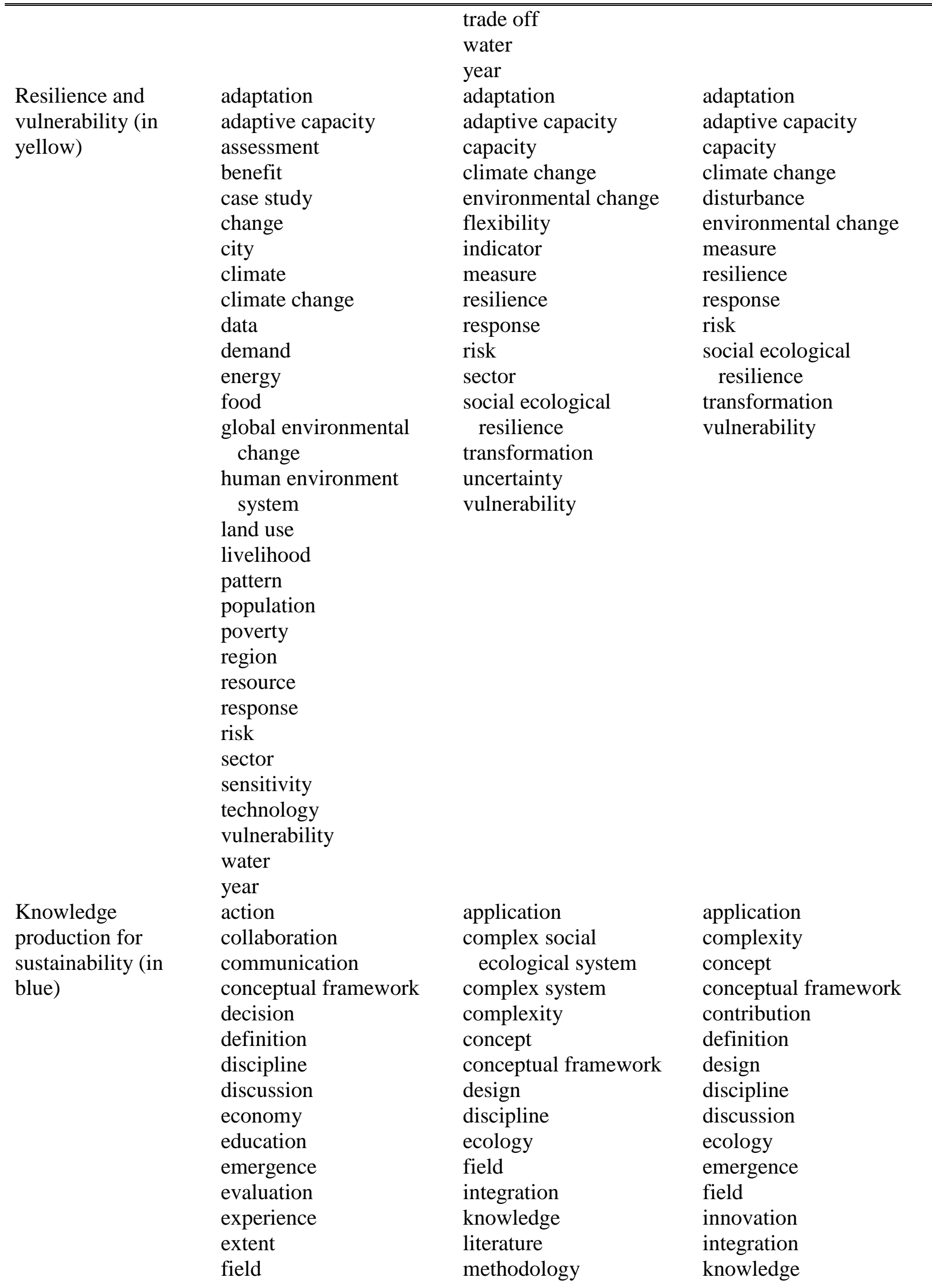


Governance for sustainability (in brown)

\begin{tabular}{|c|c|c|}
\hline $\begin{array}{l}\text { implementation } \\
\text { innovation } \\
\text { integration } \\
\text { issue } \\
\text { limitation } \\
\text { objective } \\
\text { opportunity } \\
\text { policy maker } \\
\text { potential } \\
\text { practitioner } \\
\text { principle } \\
\text { problem } \\
\text { program } \\
\text { project } \\
\text { purpose } \\
\text { relevance } \\
\text { respect } \\
\text { review } \\
\text { science } \\
\text { social science } \\
\text { solution } \\
\text { stakeholder } \\
\text { sustainability problem } \\
\text { sustainable developme } \\
\text { transdisciplinary } \\
\text { research } \\
\text { transformation } \\
\text { transition } \\
\text { university }\end{array}$ & $\begin{array}{l}\text { actor } \\
\text { adaptive governance } \\
\text { adaptive management } \\
\text { Australia } \\
\text { collaboration } \\
\text { communication } \\
\text { conflict } \\
\text { country } \\
\text { effectiveness } \\
\text { emergence } \\
\text { evaluation } \\
\text { experience } \\
\text { governance } \\
\text { government } \\
\text { group } \\
\text { implementation } \\
\text { individual } \\
\text { institution } \\
\text { interview } \\
\text { learning }\end{array}$ & $\begin{array}{l}\text { literature } \\
\text { methodology } \\
\text { perspective } \\
\text { practitioner } \\
\text { principle } \\
\text { problem } \\
\text { progress } \\
\text { purpose } \\
\text { relevance } \\
\text { review } \\
\text { science } \\
\text { social science } \\
\text { solution } \\
\text { sustainability } \\
\text { sustainability science } \\
\text { sustainable development } \\
\text { theory } \\
\text { transition }\end{array}$ \\
\hline
\end{tabular}




$\begin{array}{ll}\text { lesson } & \text { lesson } \\ \text { manager } & \text { manager } \\ \text { natural resource } & \text { network } \\ \text { management } & \text { organization } \\ \text { network } & \text { participant } \\ \text { organization } & \text { participation } \\ \text { participant } & \text { perception } \\ \text { participation } & \text { policy maker } \\ \text { perception } & \text { power } \\ \text { policy maker } & \text { project } \\ \text { project } & \text { stakeholder } \\ \text { stakeholder } & \text { success } \\ \text { success } & \text { support } \\ \text { support } & \text { trade off }\end{array}$


Table A4.1. List of words (presented in alphabetical order) comprising each cluster in the SS AND TD, SES AND TD, and (SS AND SES) AND TD semantic networks.

\begin{tabular}{|c|c|c|c|}
\hline Clusters & SS AND TD & SES AND TD & $\begin{array}{l}\text { (SS AND SES) AND } \\
\quad \mathrm{TD} \\
\end{array}$ \\
\hline $\begin{array}{l}\text { Environmental } \\
\text { change and } \\
\text { ecosystem services } \\
\text { (in green) }\end{array}$ & $\begin{array}{l}\text { application } \\
\text { climate change } \\
\text { communication } \\
\text { conservation } \\
\text { data } \\
\text { decision making } \\
\text { ecology } \\
\text { economic } \\
\text { ecosystem } \\
\text { ecosystem service } \\
\text { Europe } \\
\text { finding } \\
\text { governance } \\
\text { human } \\
\text { implementation } \\
\text { institution } \\
\text { landscape } \\
\text { methodology } \\
\text { nature } \\
\text { North America } \\
\text { policy } \\
\text { practitioner } \\
\text { resilience } \\
\text { review } \\
\text { risk } \\
\text { scale } \\
\text { social ecological system } \\
\text { social science } \\
\text { sustainability problem } \\
\text { sustainable development } \\
\text { transdisciplinary } \\
\text { sustainability science } \\
\text { uncertainty } \\
\text { vision }\end{array}$ & $\begin{array}{l}\text { agriculture } \\
\text { assessment } \\
\text { biodiversity } \\
\text { boundary } \\
\text { climate change } \\
\text { complex social } \\
\text { ecological system } \\
\text { conceptual framework } \\
\text { decision maker } \\
\text { driver } \\
\text { ecology } \\
\text { economic } \\
\text { ecosystem service } \\
\text { effect } \\
\text { future } \\
\text { human environment } \\
\text { system } \\
\text { implication } \\
\text { innovation } \\
\text { land use } \\
\text { landscape } \\
\text { methodology } \\
\text { model } \\
\text { natural science } \\
\text { pattern } \\
\text { policy maker } \\
\text { progress } \\
\text { project } \\
\text { recognition } \\
\text { response } \\
\text { social science } \\
\text { solution } \\
\text { transdisciplinary } \\
\text { approach } \\
\text { transdisciplinary } \\
\quad \text { research } \\
\text { transition }\end{array}$ & $\begin{array}{l}\text { application } \\
\text { biodiversity } \\
\text { decision making } \\
\text { diversity } \\
\text { dynamic } \\
\text { ecology } \\
\text { economic } \\
\text { ecosystem } \\
\text { ecosystem service } \\
\text { Europe } \\
\text { finding } \\
\text { governance } \\
\text { human environment } \\
\text { system } \\
\text { implementation } \\
\text { information } \\
\text { landscape } \\
\text { methodology } \\
\text { policy maker } \\
\text { power } \\
\text { principle } \\
\text { review } \\
\text { transdisciplinary } \\
\text { approach } \\
\text { transition } \\
\text { vision } \\
\text { world }\end{array}$ \\
\hline $\begin{array}{l}\text { Resilience and } \\
\text { vulnerability (in } \\
\text { yellow) }\end{array}$ & & $\begin{array}{l}\text { actor } \\
\text { adaptability } \\
\text { adaptation } \\
\text { adaptive capacity } \\
\text { adaptive governance } \\
\text { capacity } \\
\text { complex adaptive } \\
\quad \text { system }\end{array}$ & $\begin{array}{l}\text { adaptation } \\
\text { adaptive capacity } \\
\text { benefit } \\
\text { climate change } \\
\text { co-production } \\
\text { communication } \\
\text { conservation } \\
\text { decision }\end{array}$ \\
\hline
\end{tabular}




$\begin{array}{ll}\text { Knowledge } & \text { adaptation } \\ \text { production for } & \text { capacity } \\ \text { sustainability (in } & \text { co-production } \\ \text { blue) } & \text { collaboration } \\ & \text { complexity } \\ & \text { definition } \\ & \text { evidence } \\ & \text { innovation } \\ & \text { interdisciplinarity } \\ & \text { knowledge production } \\ & \text { mode } \\ & \text { participation } \\ & \text { partnership } \\ & \text { principle } \\ & \text { program } \\ & \text { progress } \\ & \text { relevance } \\ & \text { response } \\ & \text { sustainability challenge } \\ & \text { transdisciplinarity } \\ & \text { transdisciplinary } \\ & \text { approach } \\ & \text { university }\end{array}$

Governance for sustainability (in brown)

\begin{tabular}{|c|c|}
\hline $\begin{array}{l}\text { ecological system } \\
\text { environmental change } \\
\text { interview } \\
\text { knowledge co- } \\
\text { production } \\
\text { local community } \\
\text { mechanism } \\
\text { participation } \\
\text { partnership } \\
\text { place } \\
\text { resilience thinking } \\
\text { social learning } \\
\text { time } \\
\text { vulnerability }\end{array}$ & $\begin{array}{l}\text { actor } \\
\text { capacity } \\
\text { case } \\
\text { collaboration } \\
\text { design } \\
\text { experience } \\
\text { innovation } \\
\text { knowledge co- } \\
\quad \text { production } \\
\text { natural science } \\
\text { participation } \\
\text { partnership } \\
\text { place } \\
\text { program } \\
\text { project } \\
\text { region } \\
\text { response } \\
\text { social science } \\
\text { solution } \\
\text { sustainability challenge } \\
\text { sustainable development } \\
\text { transdisciplinarity }\end{array}$ \\
\hline
\end{tabular}

application

co-production

communication

complex system

conflict

conservation

contribution

decision making

definition

diversity

evaluation

government

implementation 


institution
interest
involvement
manager
natural resource
natural resource
$\quad$ management
ngo
participant
power
practitioner
risk
transdisciplinarity
trust
uncertainty
view
vision


Fig. A5. Fig. A5.1. Semantic network for all selected articles (SS and SES and SS AND TD and SES AND TD) (see also Fig. 2, Table 2); Fig. A5.2. Semantic network for all the papers citing the selected articles (see also Fig. 2). Colors represent the following thematic clusters: 1) green: environmental change and ecosystem services; 2) yellow: resilience and vulnerability; 3) blue: knowledge production for sustainability; and 4) brown: governance for sustainability.

\section{Fig. A5.1 SS and SES and SS AND TD and SES}

\section{AND TD}

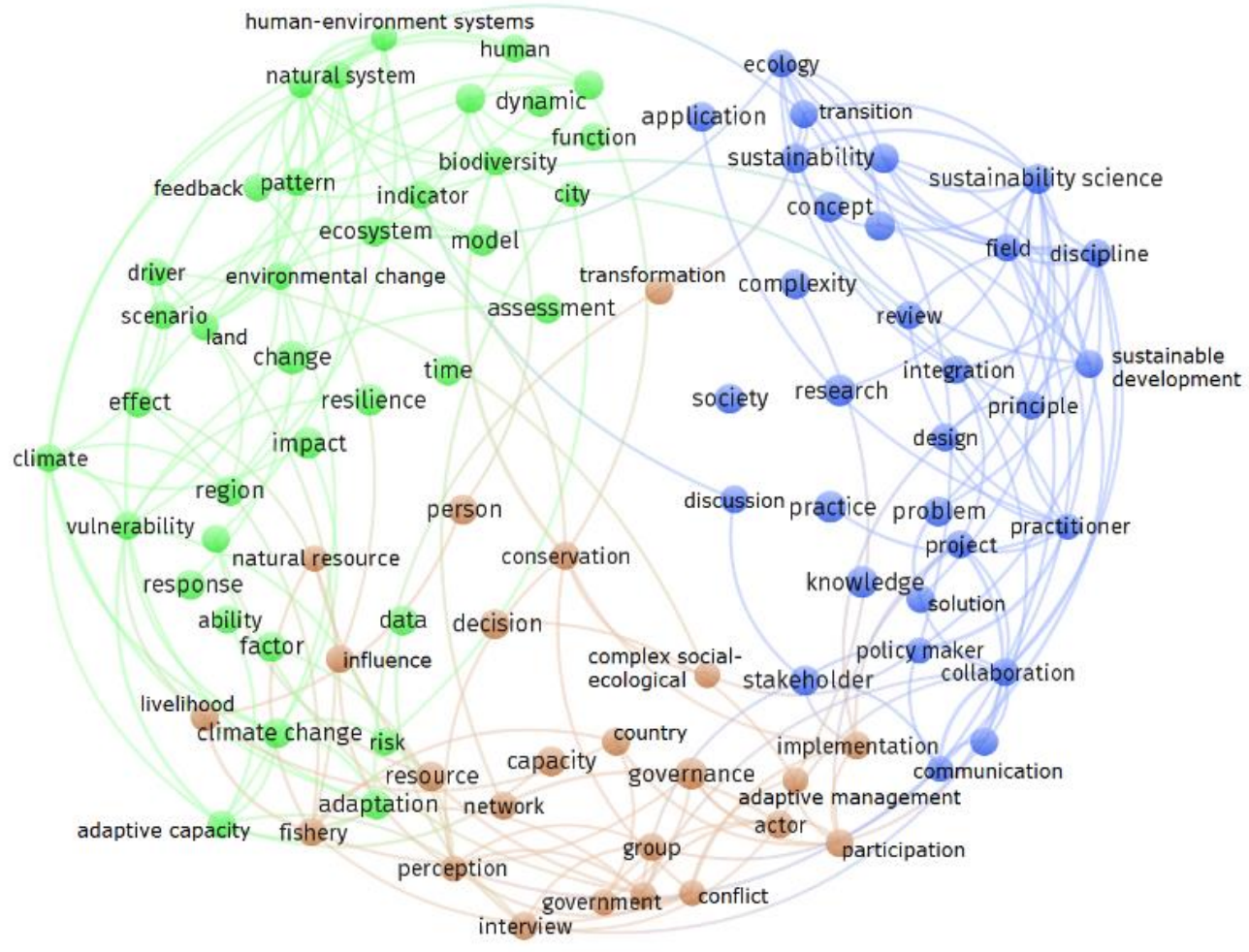

Fig. A.5.2 All citing articles of SS and SES and SS

AND TD and SES AND TD

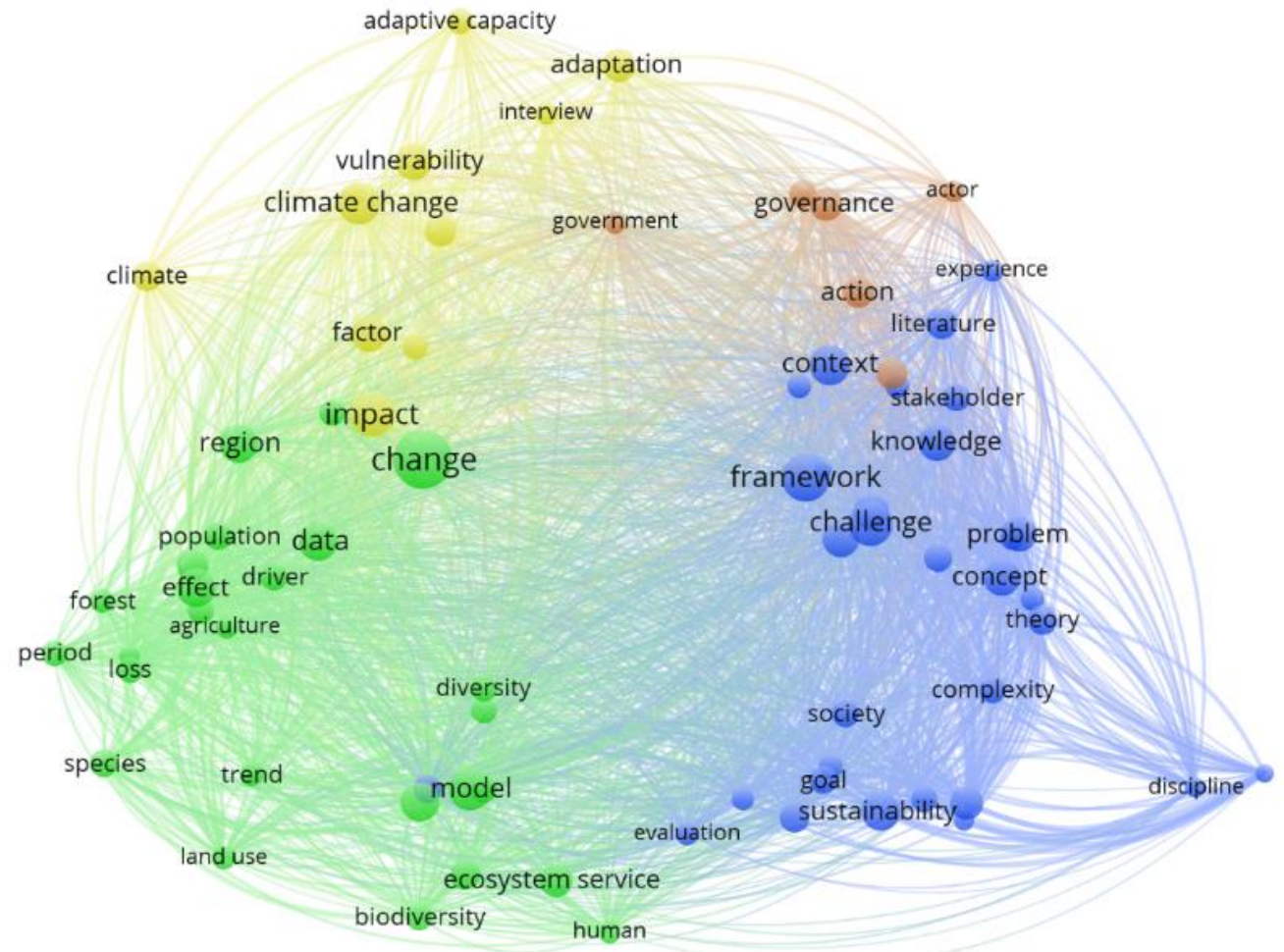

